Chapman University

Chapman University Digital Commons

Biology, Chemistry, and Environmental Sciences Science and Technology Faculty Articles and Faculty Articles and Research

7-15-2020

\title{
Global Atmospheric Budget of Acetone: Air-Sea Exchange and the Contribution to Hydroxyl Radicals
}

Siyuan Wang

Eric C. Apel

Rebecca H. Schwantes

Kelvin H. Bates

Daniel J. Jacob

See next page for additional authors

Follow this and additional works at: https://digitalcommons.chapman.edu/sees_articles

Part of the Atmospheric Sciences Commons, Environmental Chemistry Commons, Oceanography Commons, Organic Chemistry Commons, and the Other Oceanography and Atmospheric Sciences and Meteorology Commons 


\section{Global Atmospheric Budget of Acetone: Air-Sea Exchange and the Contribution to Hydroxyl Radicals}

\section{Comments}

This article was originally published in Journal of Geophysical Research: Atmospheres, volume 125, in 2020. https://doi.org/10.1029/2020JD032553

\section{Copyright}

American Geophysical Union

\section{Authors}

Siyuan Wang, Eric C. Apel, Rebecca H. Schwantes, Kelvin H. Bates, Daniel J. Jacob, Emily V. Fischer, Rebecca S. Hornbrook, Alan J. Hills, Louisa K. Emmons, Laura L. Pan, Shawn Honomichl, Simone Tilmes, Jean-François Lamarque, Mingxi Yang, Christa A. Marandino, E. S. Saltzman, Warren J. de Bruyn, Sohiko Kameyama, Hiroshi Tanimoto, Yuko Omori, Samuel R. Hall, Kirk Ullmann, Thomas B. Ryerson, Chelsea R. Thompson, Jeff Peischl, Bruce C. Daube, Róisín Commane, Kathryn McKain, Colm Sweeney, Alexander B. Thames, David O. Miller, William H. Brune, Glenn S. Diskin, Joshua P. DiGangi, and Steven C. Wofsy 


\section{JGR Atmospheres}

\section{RESEARCH ARTICLE 10.1029/2020JD032553 \\ Global Atmospheric Budget of Acetone: Air-Sea Exchange and the Contribution to Hydroxyl Radicals}

\author{
Special Section: \\ Community Earth System \\ Model version 2 (CESM2) \\ Special Collection
}

Key Points:

- We develop an online air-sea exchange module for acetone, with ocean biogeochemistry represented using data-oriented machine learning

- Two separate global acetone simulations are compared to global-scale multiseasonal airborne observations

- Global models consistently overestimate acetone in the upper troposphere over the Southern Ocean in austral winter

Supporting Information:

- Supporting Information S1

- Movie S1

- Movie S2

Correspondence to:

S. Wang,

siyuan@ucar.edu

Citation:

Wang, S., Apel, E. C., Schwantes, R. H., Bates, K. H., Jacob, D. J., \& Fischer, E. V., et al. (2020). Global atmospheric budget of acetone: Air-sea exchange and the contribution to hydroxyl radicals. Journal of Geophysical Research: Atmospheres, 125 , e2020JD032553. https://doi.org/ 10.1029/2020JD032553

Received 5 FEB 2020

Accepted 11 JUL 2020

Accepted article online 15 JUL 2020

(C)2020. American Geophysical Union. All Rights Reserved.

Siyuan Wang' (D, Eric C. Apel ${ }^{1}$ (D), Rebecca H. Schwantes ${ }^{1,2,3}$ iD, Kelvin H. Bates ${ }^{4}$, Daniel J. Jacob ${ }^{4}$, Emily V. Fischer ${ }^{5}$ (D), Rebecca S. Hornbrook ${ }^{1}$ iD, Alan J. Hills ${ }^{1}$, Louisa K. Emmons ${ }^{1}$ iD, Laura L. Pan ${ }^{1}$ iD, Shawn Honomichl ${ }^{1}$ iD, Simone Tilmes ${ }^{1}$ iD, Jean-François Lamarque ${ }^{6}$ iD, Mingxi Yang ${ }^{7}$ (D), Christa A. Marandino ${ }^{8}$, Eric S. Saltzman' ${ }^{9}$, Warren de Bruyn ${ }^{10}$, Sohiko Kameyama $^{11}$, Hiroshi Tanimoto ${ }^{12}$ iD, Yuko Omori ${ }^{12,13}$ iD, Samuel R. Hall ${ }^{1}$ iD, Kirk Ullmann $^{1}$ (D), Thomas B. Ryerson ${ }^{14}$ (D) Chelsea R. Thompson ${ }^{14,15}$ (D) Jeff Peischl ${ }^{14,15}$ (D), Bruce C. Daube ${ }^{4}$, Róisín Commane ${ }^{4,16}$ iD, Kathryn McKain ${ }^{14,15}$ iD, Colm Sweeney ${ }^{14}$ (D), Alexander B. Thames ${ }^{17}$, David O. Miller ${ }^{17}$, William H. Brune ${ }^{17}$ (D, Glenn S. Diskin ${ }^{18}$ (D, Joshua P. DiGangi ${ }^{18}$ iD, and Steven C. Wofsy ${ }^{4}$ iD

\begin{abstract}
${ }^{1}$ Atmospheric Chemistry Observations and Modeling Laboratory, National Center for Atmospheric Research, Boulder, CO, USA, ${ }^{2}$ Now at Cooperative Institute for Research in Environmental Sciences, University of Colorado Boulder, Boulder, CO, USA, ${ }^{3}$ Now at Chemical Sciences Laboratory, National Oceanic and Atmospheric Administration, Boulder, CO, USA, ${ }^{4}$ School of Engineering and Applied Sciences, Harvard University, Cambridge, MA, USA, ${ }^{5}$ Department of Atmospheric Science, Colorado State University, Fort Collins, CO, USA, ${ }^{6}$ Climate and Global Dynamics, National Center for Atmospheric Research, Boulder, CO, USA, ${ }^{7}$ Plymouth Marine Laboratory, Plymouth, UK, ${ }^{8}$ Forschungsbereich Marine Biogeochemie, GEOMAR, Helmholtz-Zentrum für Ozeanforschung Kiel, Kiel, Germany, ${ }^{9}$ Department of Earth System Science, University of California, Irvine, CA, USA, ${ }^{10}$ Department of Chemistry, Schmid College of Science and Technology, Chapman University, Orange, CA, USA, ${ }^{11}$ Faculty of Environmental Earth Science, Hokkaido University, Sapporo, Japan, ${ }^{12}$ Center for Global Environmental Research, National Institute for Environmental Studies, Tsukuba, Japan, ${ }^{13}$ Faculty of Life and Environmental Sciences, University of Tsukuba, Tsukuba, Japan, ${ }^{14}$ Earth System Research Laboratory, National Oceanic and Atmospheric Administration, Boulder, CO, USA, ${ }^{15}$ Cooperative Institute for Research in Environmental Sciences, University of Colorado Boulder, Boulder, CO, USA, ${ }^{16}$ Department of Earth and Environmental Sciences, Lamont-Doherty Earth Observatory, Columbia University, New York, NY, USA, ${ }^{17}$ Department of Meteorology and Atmospheric Science, Pennsylvania State University, University Park, PA, USA, ${ }^{18}$ Langley Research Center, National Aeronautics and Space Administration, Hampton, VA, USA
\end{abstract}

Abstract Acetone is one of the most abundant oxygenated volatile organic compounds (VOCs) in the atmosphere. The oceans impose a strong control on atmospheric acetone, yet the oceanic fluxes of acetone remain poorly constrained. In this work, the global budget of acetone is evaluated using two global models: CAM-chem and GEOS-Chem. CAM-chem uses an online air-sea exchange framework to calculate the bidirectional oceanic acetone fluxes, which is coupled to a data-oriented machine-learning approach. The machine-learning algorithm is trained using a global suite of seawater acetone measurements. GEOS-Chem uses a fixed surface seawater concentration of acetone to calculate the oceanic fluxes. Both model simulations are compared to airborne observations from a recent global-scale, multiseasonal campaign, the NASA Atmospheric Tomography Mission (ATom). We find that both CAM-chem and GEOS-Chem capture the measured acetone vertical distributions in the remote atmosphere reasonably well. The combined observational and modeling analysis suggests that (i) the ocean strongly regulates the atmospheric budget of acetone. The tropical and subtropical oceans are mostly a net source of acetone, while the high-latitude oceans are a net sink. (ii) CMIP6 anthropogenic emission inventory may underestimate acetone and/or its precursors in the Northern Hemisphere. (iii) The MEGAN biogenic emissions model may overestimate acetone and/or its precursors, and/or the biogenic oxidation mechanisms may overestimate the acetone yields. (iv) The models consistently overestimate acetone in the upper troposphere-lower stratosphere over the Southern Ocean in austral winter. (v) Acetone contributes up to 30-40\% of hydroxyl radical production in the tropical upper troposphere/lower stratosphere.

Plain Language Summary Acetone is widely observed in the Earth's atmosphere, with mixing ratios ranging from parts-per-trillion levels in the stratosphere to parts-per-billion levels in polluted regions. Acetone is directly emitted from a wide variety of natural and anthropogenic sources and is also produced from the photochemical oxidation of a number of precursors. The role of the ocean is complicated; 
acetone is produced in the ocean from the photolysis of colored dissolved organic materials or from biological processes but is also removed via microbial uptake. Previous studies have found that the direction and magnitude of oceanic acetone fluxes vary dramatically with seasons and locations. In this work, we use a data-oriented machine-learning approach to predict the surface seawater concentration of acetone, leveraging in situ acetone measurements in the surface seawater around the globe. This machine learning-based approach shows promising potential and can be expanded to the bottom-up oceanic emissions of other climate-relevant compounds.

\section{Introduction}

Oxygenated volatile organic compounds (OVOCs) influence the oxidative capacity of the atmosphere, affecting its self-cleaning capacity and hence the fate of pollutants (Monks, 2005). Acetone $\left(\mathrm{CH}_{3} \mathrm{COCH}_{3}\right)$ is one of the most abundant OVOCs identified in the atmosphere, with mixing ratios ranging from ppt (parts per trillion) levels in the remote atmosphere to ppb (parts per billion) levels in polluted regions. Acetone is directly emitted into the atmosphere from a variety of natural and anthropogenic sources, including terrestrial ecosystems (Hu et al., 2013), biomass burning (Holzinger et al., 1999), vehicular exhaust (Kean et al., 2001), industrial and combustion processes (Singh et al., 1994a), and solvent use (Yuan et al., 2010). Acetone is also produced from the photochemical oxidation of a number of volatile organic compound (VOC) precursors, such as terpenes (Lee et al., 2006) and alkanes (Atkinson \& Arey, 2003). Major sinks of acetone in the atmosphere include photolysis, oxidation by hydroxyl radicals (OH), and dry deposition (Fischer et al., 2012) (wet deposition contribution is likely small).

The ocean plays a key role in the global atmospheric budget of acetone. Jacob et al. (2002) showed that to reconcile existing observations, the ocean must regulate atmospheric acetone both on the global and regional scale. Jacob et al. (2002) used a global chemical transport model (GEOS-Chem) with parameterized oceanic acetone emissions. Fischer et al. (2012) included updated (slower) photolysis loss in GEOS-Chem and found that with this change to the lifetime of acetone, a large net ocean source is not needed to explain observed atmospheric mixing ratios. Fischer et al. (2012) proposed that the ocean may both emit or uptake acetone; the direction and magnitude of the oceanic acetone fluxes show substantive spatial and seasonal variations. Due to the sparse availability of acetone measurements in the surface seawater, Fischer et al. (2012) prescribed a fixed surface seawater concentration of acetone ( $\left.15 \mathrm{nmol} \mathrm{L}^{-1}\right)$, and air-sea fluxes of acetone were calculated based on this constant value. Brewer et al. (2017) show that predictions of atmospheric acetone abundances in the tropics and over the Southern Hemisphere oceans are particularly sensitive to uncertainty associated with the concentration of acetone in surface seawater. Over the past decade, more surface seawater measurements of acetone have become available, with improved spatial and seasonal coverage (Beale et al., 2013; Dixon et al., 2013, 2014; Hudson et al., 2007; Kameyama et al., 2010; Marandino et al., 2005; Schlundt et al., 2017; Yang, Beale, et al., 2014; Yang, Blomquist, et al., 2014). Marine acetone fluxes have been estimated indirectly based on acetone measurements in both the surface seawater and the overlying atmosphere (Taddei et al., 2009; Zhou \& Mopper, 1997). Direct flux measurements have also been reported using the eddy covariance method (Marandino et al., 2005; Yang, Beale, et al., 2014) and the near-surface vertical gradient method (Tanimoto et al., 2014). These observations provide much better constraints on air-sea exchange.

The photolysis of acetone leads to the production of hydrogen oxide radicals $\left(\mathrm{HO}_{x}=\mathrm{OH}+\mathrm{HO}_{2}\right)$. Due to its relatively long global atmospheric lifetime (approximately a few weeks; Fischer et al., 2012; Khan et al., 2015), acetone may undergo long-range transport and contribute to the production of peroxyacetyl nitrate (PAN), an important reservoir of nitrogen oxides $\left(\mathrm{NO}_{x}=\mathrm{NO}+\mathrm{NO}_{2}\right)$ (Fischer et al., 2014) and $\mathrm{HO}_{x}$ radicals. In particular, previous studies have proposed that acetone may contribute substantially to $\mathrm{HO}_{x}$ production in the upper troposphere and lower stratosphere, where $\mathrm{OH}$ production from ozone (ozone photolysis followed by the reaction between water vapor and the singlet oxygen atom, $\left.O\left({ }^{1} \mathrm{D}\right)\right)$ is less efficient, due to lower water vapor concentrations (Arnold et al., 1986, 1997; Jaeglé et al., 2001; Singh et al., 1994, 1995). The temperature and wavelength dependency of acetone photolysis quantum yield was revisited (Blitz et al., 2004) since many of these earlier studies were published, and it was found that the photolysis of acetone is $\sim 3$ times slower than previously estimated in the upper troposphere. A recent study utilizing sensors mounted on commercial aircrafts with routes between Europe and Asia indicated that in the upper troposphere/lower 
stratosphere the $\mathrm{HO}_{x}$ production from acetone, considering the revised acetone photolysis (Blitz et al., 2004), could still be almost as important as the $\mathrm{O}_{3}-\mathrm{O}\left({ }^{1} \mathrm{D}\right)-\mathrm{H}_{2} \mathrm{O}$ mechanism (Neumaier et al., 2014). Despite the wide spatial coverage $\left(35-60^{\circ} \mathrm{N}\right.$ and $124^{\circ} \mathrm{W}$ to $142^{\circ} \mathrm{E}$ ), the commercial airlines involved in the study (Neumaier et al., 2014) sampled relatively polluted regions with high acetone abundances, as indicated by the recent satellite-borne acetone retrievals using the Infrared Atmospheric Sounding Interferometer (Franco et al., 2019). The importance of acetone to $\mathrm{HO}_{x}$ production on the global scale, particularly in the remote atmosphere, may not be directly inferred from that study (Neumaier et al., 2014).

In this work, we revisit the global atmospheric budget of acetone using two global models, the Community Atmosphere Model with Chemistry (CAM-chem), and GEOS-Chem. The CAM-chem model uses a newly developed bottom-up oceanic emission inventory of acetone, with a recently developed online oceanic emission module (Wang, Hornbrook, et al., 2019) and a novel data-oriented machine-learning approach representing ocean biogeochemistry control over this process (Wang, Kinnison, et al., 2019). The GEOS-Chem model uses the configuration of Fischer et al. (2012) for oceanic acetone emissions. Modeling results are evaluated using observations obtained from a recent global-scale, multiseasonal airborne campaign, the National Aeronautics and Space Administration (NASA) Atmospheric Tomography Mission (ATom). The acetone contribution to $\mathrm{HO}_{x}$ production is investigated on a global scale.

\section{Methods}

\subsection{CAM-Chem Model}

CAM-chem (Lamarque et al., 2012; Tilmes et al., 2015) is the atmospheric component of a widely used chemistry-climate model, the National Center for Atmospheric Research (NCAR) Community Earth System Model (CESM). In this work, CAM-chem (from CESM2.1.1) is nudged (Tilmes et al., 2015) to the NASA Modern-Era Retrospective analysis for Research and Applications, Version 2 (MERRA-2) meteorology fields with a horizontal resolution of $0.9^{\circ}$ latitude $\times 1.25^{\circ}$ longitude and 56 vertical levels (up to $3 \mathrm{hPa}$ ). The chemistry scheme is based on that in CESM2.1.1, which includes a detailed representation of tropospheric and stratospheric chemistry (Emmons et al., 2020) and an updated monoterpene and isoprene mechanism (Schwantes et al., 2020). This chemical mechanism includes acetone production from propane, BIGALK (including butanes and larger alkanes), BIGENE (butenes and larger alkenes), $\alpha$-pinene, $\beta$-pinene, and myrcene, as well as acetone removal by $\mathrm{OH}$ oxidation and photolysis. We also tested acetone oxidation by chlorine radical (Burkholder et al., 2015). The temperature and pressure-dependent photolysis of acetone (Blitz et al., 2004) is implemented in CAM-chem. In this work, CAM-chem includes anthropogenic emissions from the Coupled Model Intercomparison Project Phase 6 (CMIP6) inventory (Hoesly et al., 2018), biomass burning emissions from the Fire INventory from NCAR (FINN version 1.5; Wiedinmyer et al., 2011), and biogenic VOC (BVOC) emissions calculated online using the Model of Emissions of Gases and Aerosols from Nature (MEGAN v2.1; Guenther et al., 2012). Dry deposition velocities in CAM-chem are calculated online depending on surface types (more details are given in section 6). In this work, CAM-chem is spun-up for 3 years to remove the effects of initial conditions, and we use simulations from June 2016 to May 2017 for analysis.

The oceanic fluxes of acetone are calculated using the Online Air-Sea Interface for Soluble Species (OASISS) developed for CESM (Wang, Hornbrook, et al., 2019), based on the widely used two-layer model framework (Johnson, 2010; Liss \& Slater, 1974). In brief, the air-sea exchange is described by the airside and waterside transfer velocities $\left(k_{\text {air }}\right.$ and $\left.k_{\text {water }}\right)$. The $k_{\text {air }}$ term is based on the National Oceanic and Atmospheric Administration (NOAA) COARE algorithm (Jeffery et al., 2010), with the addition of the still air diffusive flux adjustment (Mackay \& Yeun, 1983). The $k_{\text {water }}$ term is based on Nightingale et al. (2000). This OASISS model framework calculates the bidirectional fluxes of trace gases considering the local physical state of the ocean (sea surface temperature, salinity, and waves/bubbles) and the atmosphere (temperature, pressure, and wind); the oceanic emissions are fully coupled with the atmospheric chemistry and dynamics.

The surface seawater concentrations of acetone (monthly climatology with a horizontal resolution of $0.9^{\circ}$ latitude $\times 1.25^{\circ}$ longitude; used to drive the air-sea exchange) are predicted by an observationally trained machine-learning algorithm, trained by in situ surface seawater observations of acetone around the globe. The machine-learning approach is described elsewhere (Wang, Kinnison, et al., 2019). In brief, a random 
forest regression algorithm (Breiman, 2001; Pedregosa et al., 2011) is linked to the ocean model and marine ecosystem model of CESM. The random forest is trained by surface seawater observations (Table 1) and ocean physical and biogeochemical parameters (independent variables), including sea surface temperature, salinity, photosynthetically active radiation, nutrients (phosphate, nitrate, iron), oxygen, and chlorophyll contents in different phytoplankton groups. These ocean physical and biogeochemical parameters are discussed in Wang, Kinnison, et al. (2019) and references therein. The combination of these independent variables represents the ocean biogeochemical control. To reduce the chance of overtraining, a fraction of the entire data set (85\%) is randomly sampled as the training data set, and the remaining (15\%) is used as testing data set. Due to the sparse availability of seawater observations, the machine-learning algorithm produces a monthly climatology. We show in section 3 that this observationally trained machine-learning framework captures the seasonal variations and large-scale features revealed in the available seawater observations. The combination of the physics-based OASISS and the observationally trained machine-learning algorithm represent both the physical forcing and the biogeochemistry control on the air-sea exchange process.

\subsection{GEOS-Chem Model}

GEOS-Chem is a widely used global chemical transport model with a detailed representation of tropospheric chemistry (Fischer et al., 2012; Jacob et al., 2002; etc.). GEOS-Chem is driven by the NASA GEOS-5 assimilated meteorological data. The GEOS-Chem model used in this work (v11-02d) is run at a horizontal resolution of $2.0^{\circ}$ latitude $\times 2.5^{\circ}$ longitude and 72 vertical layers (up to $1 \mathrm{~Pa}$ ). The chemical mechanism used in these GEOS-Chem simulations is largely consistent with the basic v11-02d mechanism, which uses a monoterpene oxidation scheme developed by Fisher et al. (2016) but also includes a recently updated isoprene oxidation mechanism (Bates \& Jacob, 2019). The temperature and pressure-dependent photolysis of acetone (Blitz et al., 2004) is also implemented in this version of GEOS-Chem. Oceanic emissions of acetone are calculated in the same way as described in Fischer et al. (2012), based on a two-layer model framework (Johnson, 2010; Liss \& Slater, 1974) but with a constant surface seawater concentration $\left(15 \mathrm{nmol} \mathrm{L}^{-1}\right)$. The default GEOS-Chem configuration uses anthropogenic emissions from the Emissions Database for Global Atmospheric Research (EDGAR) version 4.2, with emissions in certain regions overwritten by regional emission inventories (details can be found at http://wiki.seas.harvard.edu/geos-chem/index.php/ Emissions_and_Deposition_Working_Group\#Recommended_Default_Emission_Inventories). In addition, GEOS-Chem uses biomass burning emissions from Global Fire Emission Database (GFED) version 4 (van der Werf et al., 2017), as well as biogenic emissions from MEGAN version 2.1 (Guenther et al., 2012). In this work, the emissions and chemistry time step was set to $20 \mathrm{~min}$; the transport time step was set to $10 \mathrm{~min}$. GEOS-Chem uses a fixed dry deposition velocity for acetone $\left(0.1 \mathrm{~cm} \mathrm{~s}^{-1}\right.$; section 6). GEOS-Chem is spun-up for 1.5 years, and simulations from June 2016 to May 2017 are used for analysis.

\subsection{The NASA ATom Campaign}

In the present work, the airborne acetone measurements from the first and second deployments of the NASA ATom field campaign (ATom-1 and ATom-2) are used for model comparison. ATom-1 and ATom-2 took place July-August 2016 and January-February 2017, respectively. During ATom, the heavily instrumented NASA DC-8 aircraft transected the lengths of the Pacific and Atlantic Oceans, regularly profiling from the marine boundary layer to the upper troposphere/lower stratosphere. During ATom-1 and ATom-2, acetone and other trace gases including hydrogen cyanide $(\mathrm{HCN})$, acetonitrile $\left(\mathrm{CH}_{3} \mathrm{CN}\right)$, propane $\left(\mathrm{C}_{3} \mathrm{H}_{8}\right)$, $i$-butane $(i$ $\left.\mathrm{C}_{4} \mathrm{H}_{10}\right)$, and $n$-butane $\left(n-\mathrm{C}_{4} \mathrm{H}_{10}\right)$ were measured with the NCAR Trace Organic Gas Analyzer (TOGA) (Apel et al., 2003, 2015), which uses fast online gas chromatography and mass spectrometry to provide mixing ratios of a large suite of VOCs. The inlet design and the analytical system of TOGA used for ATom have been described in detail elsewhere (Wang, Hornbrook, et al., 2019). In addition, $\mathrm{O}_{3}$ and NO were measured using the NOAA $\mathrm{NO}_{\mathrm{y}} \mathrm{O}_{3}$ four-channel chemiluminescence (CL) instrument (Ryerson et al., 2000); OH radical mixing ratios were measured using the Pennsylvania State University Airborne Tropospheric Hydrogen Oxides Sensor (ATHOS) (Faloona et al., 2004); photolysis frequencies for relevant compounds were calculated using CCD Actinic Flux Spectroradiometers (CAFS) measurements (Shetter \& Müller, 1999). Carbon monoxide (CO) was measured using a Quantum Cascade Laser Spectrometer (QCLS; McManus et al., 2005; Santoni et al., 2014) and a Picarro analyzer (modified G2401m; Crosson, 2008; Karion et al., 2013). The CO quantity (CO.X in the merge files) uses Picarro CO data to fill calibration gaps in the QCLS CO measurements, after subtracting the low-pass filtered difference between the QCLS and the Picarro measurement. Water vapor 
Table 1

Ship-Based Surface Seawater Acetone Measurements Used to Train the Machine-Learning Algorithm in This Work

\begin{tabular}{|c|c|c|}
\hline Machine-learning training data set & Region & Month(s) \\
\hline Yang, Blomquist, and Nightingale (2014) & Atlantic $\left(50^{\circ} \mathrm{N}\right.$ to $\left.45^{\circ} \mathrm{S}\right)$ & October-November \\
\hline Yang, Beale, et al. (2014) & Northern Atlantic $\left(65-40^{\circ} \mathrm{N}\right)$ & October-November \\
\hline Dixon et al. (2014) & English Channel $\left(50^{\circ} \mathrm{N}\right)$ & January-November \\
\hline Beale et al. (2013) & Atlantic $\left(50^{\circ} \mathrm{N}\right.$ to $\left.40^{\circ} \mathrm{S}\right)$ & October-November \\
\hline Kameyama et al. (2010) & Northern Pacific $\left(49-43^{\circ} \mathrm{N}\right)$ & August \\
\hline Hudson et al. (2007) & Nordic seas $\left(79-68^{\circ} \mathrm{N}\right)$ & June \\
\hline Marandino et al. (2005) & Pacific $\left(45-5^{\circ} \mathrm{N}\right)$ & May-July \\
\hline Marandino et al., unpublished ${ }^{\mathrm{a}}$ & Pacific $\left(2-47^{\circ} \mathrm{S}\right)$ & January \\
\hline
\end{tabular}

${ }^{\mathrm{a}}$ Acetone measurements during the Knorr 06 study are not published, but the Knorr 06 study is described elsewhere (Marandino et al., 2009).

was measured using a Diode Laser Hygrometer (DLH) (Diskin et al., 2002). All airborne measurements are from the 2 min TOGA merge products unless otherwise noted.

\section{Seawater Concentrations and Oceanic Fluxes of Acetone}

Figure 1 shows the surface water acetone concentrations (monthly mean climatology) predicted using the observationally trained machine-learning algorithm, compared to ship-borne observations. As shown in Figure 1, the machine learning captures the spatial and seasonal variations revealed from the limited seawater observational data set reasonably well. The mean absolute percentage error $\left(M A P E \equiv \frac{100}{n} \sum_{i=1}^{n} \mid\right.$ $\frac{M O D_{i}-O B S_{i}}{O B S_{i}}$, where $O B S_{i}$ and $M O D_{i}$ denote the individual observations and modeled results, respectively, and $n$ is the number of samples) of the machine learning-predicted surface seawater acetone is $12.6 \%$, and the root-mean-square error $\left(R M S E \equiv \sqrt{\frac{\sum_{i=1}^{N}\left(M O D_{i}-O B S_{i}\right)^{2}}{N}}\right)$ is $4.8 \mathrm{nmol} \mathrm{L}^{-1}$. The linear correlation between the observed and predicted surface seawater acetone is shown in supporting information Figure $\mathrm{S} 1$ (slope $=0.89, r=0.95, n=436$ ).

The observationally trained machine-learning algorithm reveals interesting insights. First, of all the independent variables used in this work (section 2.1), photosynthetically active radiation is found to be the most important, which is consistent with previous findings that acetone is produced from photochemical disassociation of colored dissolved organic matter (CDOM) in the surface seawater (Kieber et al., 1990; Zhou \& Mopper, 1997). Second, elevated acetone is often found in oligotrophic oceans, especially the Northern Atlantic subtropical gyre, while highly productive regions (e.g., Southern Ocean) are often associated with low acetone levels. This may be due to enhanced acetone consumption in the productive regions (Dixon et al., 2013, 2014) and accumulation of acetone in the ocean gyres. As shown in Figure 1, surface seawater acetone is elevated in the tropical and subtropical Pacific Ocean all year long $\left(>15 \mathrm{nmol} \mathrm{L}^{-1}\right)$. The high-latitude oceans show remarkable seasonal variations: Northern Pacific and Atlantic show low surface seawater acetone in boreal winter $\left(<7 \mathrm{nmol} \mathrm{L}^{-1}\right)$, which is more than doubled in boreal summer (16$\left.20 \mathrm{nmol} \mathrm{L}^{-1}\right)$. The Southern Ocean shows the same seasonal trend, with elevated surface seawater concentrations in austral summer (14-18 $\left.\mathrm{nmol} \mathrm{L}{ }^{-1}\right)$ and lower concentrations in austral winter $\left(3-6 \mathrm{nmol} \mathrm{L}^{-1}\right)$. Note that in general the availability of the seawater acetone observations for the training of the machine learning is very sparse, especially in the majority of the Pacific Ocean, Indian Ocean, and the high-latitude Southern Ocean. Figure 1 implies that a machine-learning approach holds promising potential in leveraging existing in situ observations. Future ship-based studies should target these regions for a better constraint on the global distribution of the surface seawater acetone; the performance of the machine-learning approach can be further improved as more observations become available.

Figure 2 shows the CAM-chem calculated oceanic acetone fluxes, using the machine learning-predicted surface seawater acetone concentrations, as well as oceanic acetone flux observations for comparison. The online air-sea exchange module is fully coupled with atmospheric dynamics and chemistry; therefore, the 


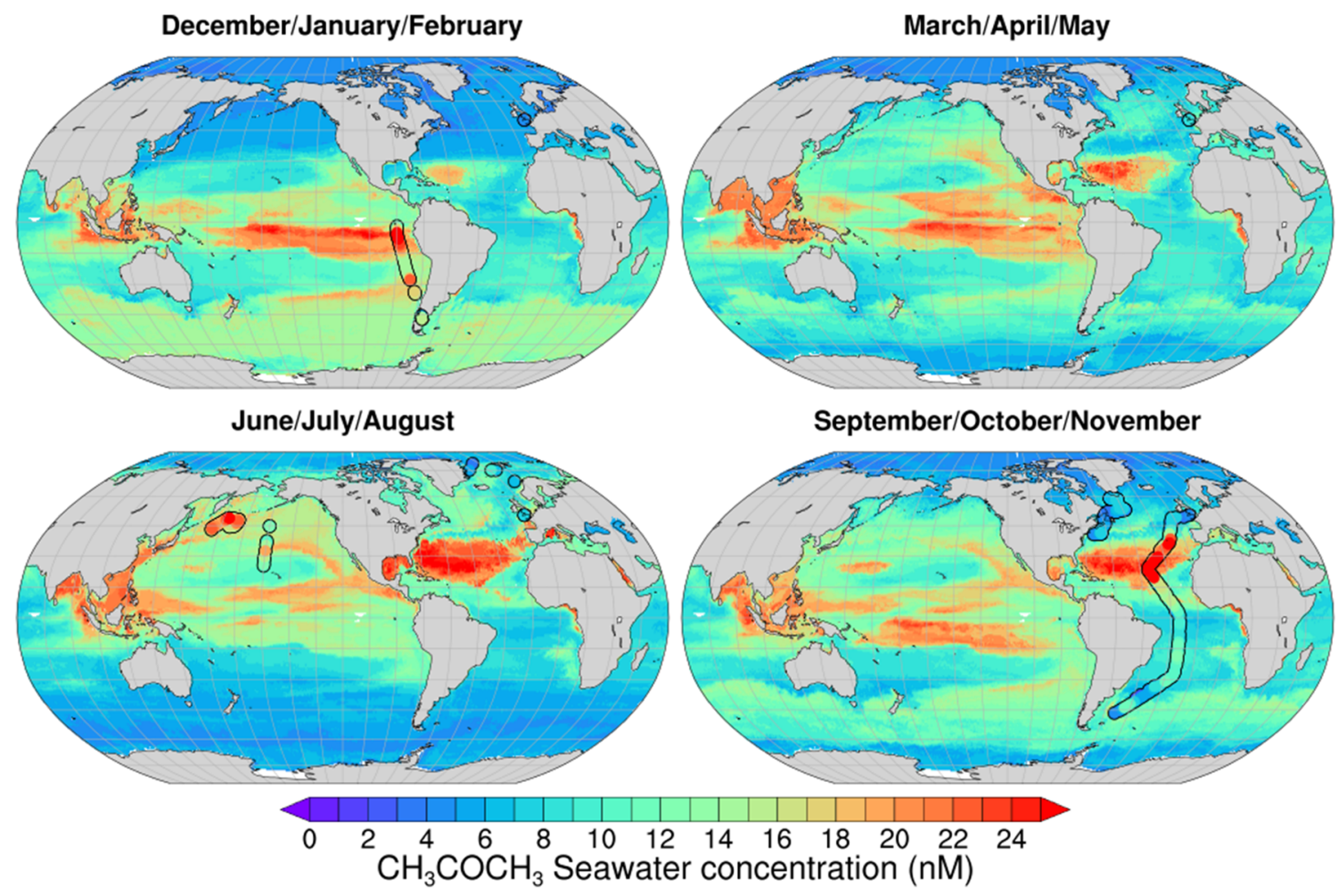

Figure 1. Machine learning-predicted monthly climatology of the surface seawater concentration of acetone grouped in different seasons (background), ship-based surface seawater acetone observations (colored dots) from the literature (Table 1).

calculated oceanic fluxes depend on the concentration in the surface atmosphere as well. Note that although the machine learning-predicted surface seawater acetone is a monthly climatology, the oceanic and atmospheric physical parameters that are used to determine the oceanic fluxes (such as sea surface temperature and meteorology) have interannual variations; therefore, the calculated oceanic emission fluxes can also have interannual variations (driven by the physical forcing in the ocean and the atmosphere). However, for the studied period (2013-2017), interannual variability in predicted oceanic acetone fluxes are not large on a global scale. As shown in Figure 2, the modeled and observed oceanic fluxes, although in different years, show consistent large-scale features. For instance, the Northern Pacific and Atlantic Oceans are a large net sink for acetone in boreal winter; there is a high abundance of acetone in continental outflows from the polluted regions (e.g., Asia and North America) that passes over cold water (Henry's law constant increases with decreasing temperature). The tropical and subtropical oceans, on the other hand, are generally a net source for acetone, except for the deep tropics $\left(10^{\circ} \mathrm{N}\right.$ to $10^{\circ} \mathrm{S}$ ) in boreal summer, where acetone from continental sources (especially from the biogenic sources in the Amazon) shows a stronger tendency to deposit into the ocean. We performed a tagged CAM-chem simulation to investigate the contribution of biogenic sources of acetone. As shown in Figure S2, biogenic acetone (including primary emission calculated by MEGAN and secondary production from terpenes) reached up to $400 \mathrm{ppt}$ in the marine boundary layer over the deep tropical Pacific $\left(10^{\circ} \mathrm{N}\right.$ to $\left.10^{\circ} \mathrm{S}\right)$ in summer and fall (JuneNovember), nearly two thirds of the total modeled acetone. This plume of biogenic acetone largely drives the downward flux over the deep tropical Pacific $\left(10^{\circ} \mathrm{N}\right.$ to $\left.10^{\circ} \mathrm{S}\right)$.

Spatial variations in the net fluxes in Figure 2 show similarity to those presented in Fischer et al. (2012), despite their adoption of a single surface seawater acetone concentration. Section S1 in the supporting information provides more details on the similarity to Fischer et al. (2012) and the possible reasons behind it. Note that the magnitude of the fluxes in certain regions appear to be underestimated by the CAM-chem model. For example, larger downward fluxes were reported over the Northern Pacific (Marandino et al., 2005) and Northern Atlantic (Yang, Beale, et al., 2014), while the modeled fluxes in the same seasons and regions are smaller. This may be due to interannual variability (observations and the model represent different 

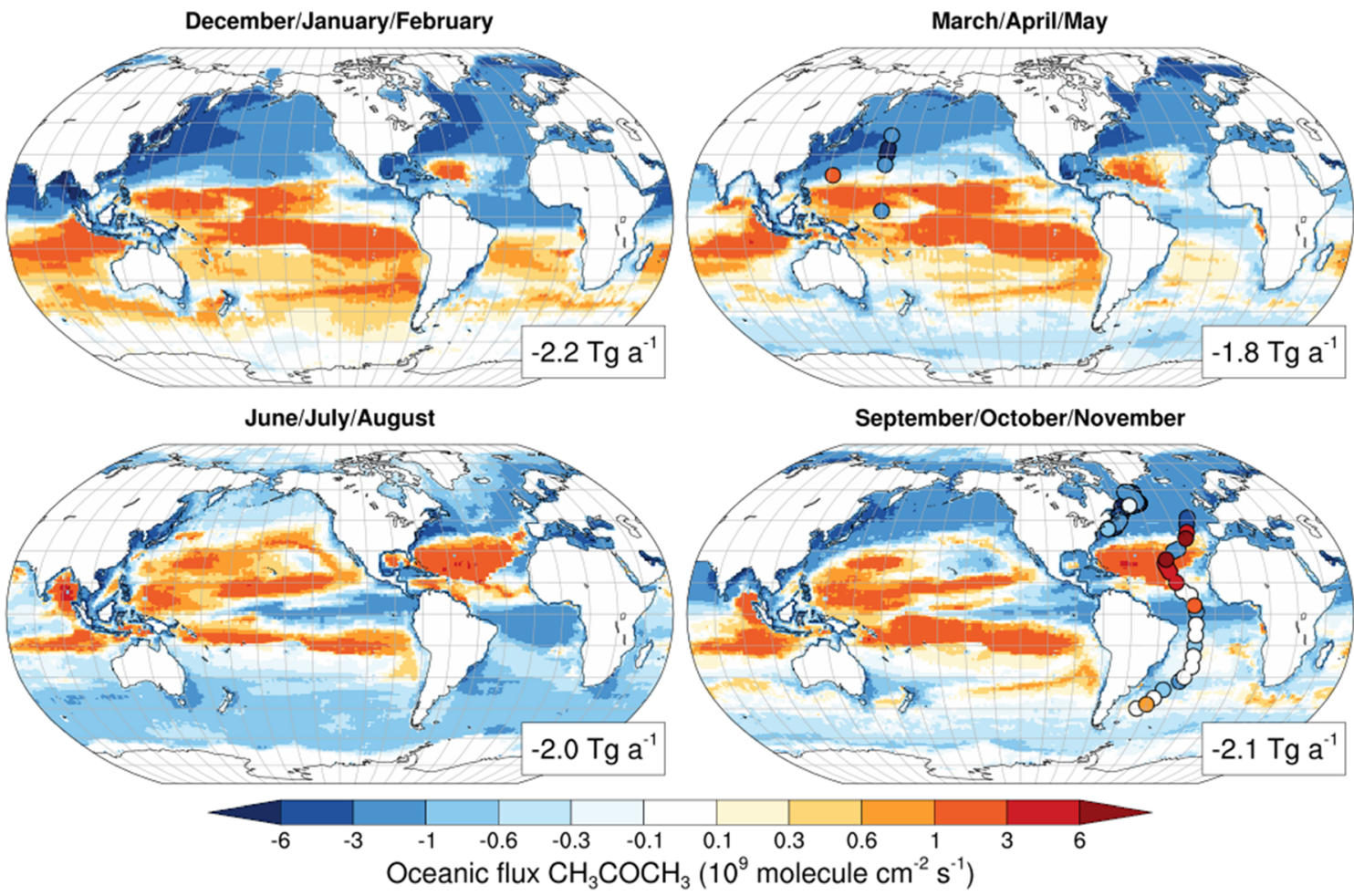

Figure 2. CAM-chem predicted net oceanic fluxes of acetone in different seasons (background), using the machine learning-predicted surface seawater concentration, as well as oceanic acetone flux measurements (colored dots) from the literature (Marandino et al., 2005; Tanimoto et al., 2014; Yang, Beale, et al., 2014; Yang, Blomquist, \& Nightingale, 2014). Net oceanic acetone fluxes in each season are given in boxes, with negative values represent net downward fluxes. Note the color bar is in log scale.

years), uncertainties in the air-sea exchange model (uncertainty on the order of 100\%; Carpenter \& Nightingale, 2015; Johnson, 2010) or an underestimation of acetone in the continental outflows from the more polluted regions (such as Asia and North America). We discuss this further in section 4 via a comparison of vertical profiles. Figure 2 also shows that there are large regions in the tropics and over the Southern Hemispheric Pacific, Indian Ocean, and high-latitude Southern Ocean where there are no comparable observations. Oceanic acetone flux measurements in these regions are highly desirable, especially flux measurements using advanced techniques such as the eddy covariance method. Overall, our approach of using an observationally trained machine-learning algorithm to represent the ocean biogeochemistry control on the air-sea exchange of trace gases is a promising alternative of the highly simplified parameterization in Earth system models.

\section{Comparison to the Airborne Observations During ATom}

In this section, we compare both CAM-chem (with and without oceanic acetone fluxes) and GEOS-Chem (with oceanic acetone fluxes) modeled vertical profiles of acetone in the remote troposphere in different regions over the Pacific and Atlantic to airborne observations from the ATom-1 (July-August 2016) and ATom-2 (January-February 2017) campaigns. The modeling outputs are sampled along the flight tracks unless otherwise noted. The flight tracks (over the oceans only) for ATom-1 and ATom-2 are given in Figure 3, as well as the CAM-chem and GEOS-Chem modeled monthly mean total acetone columns in August 2016 and February 2017. The large-scale features in the total acetone column are very similar between the two models. Both models predict elevated acetone column over the Amazon and Africa, due to the primary acetone emissions from the terrestrial ecosystem and the photochemical production from BVOCs. In addition, the models also predict elevated acetone columns over East Asia and North America from anthropogenic emissions of hydrocarbons (mainly alkanes). The measured and model predicted 

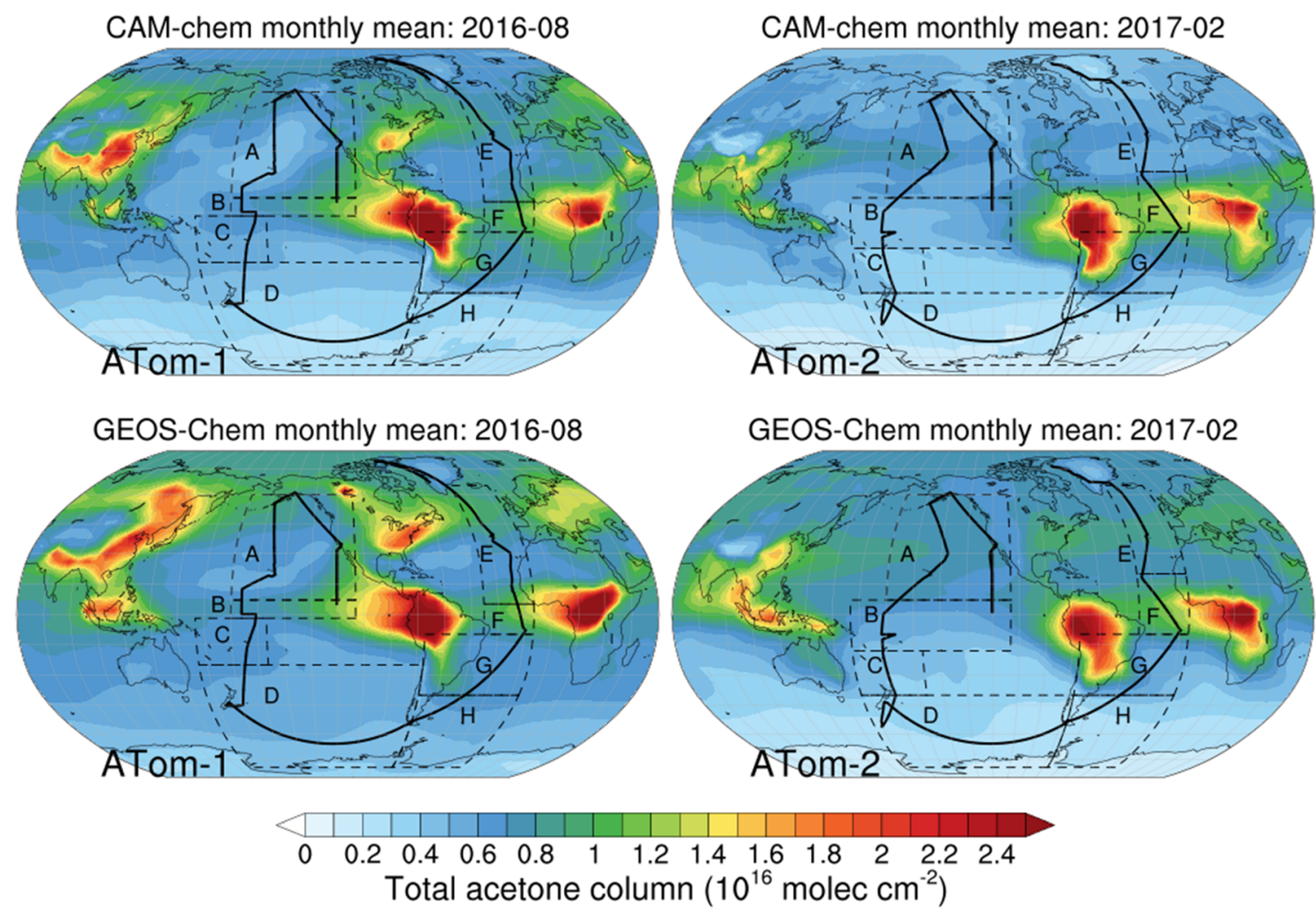

Figure 3. CAM-chem and GEOS-Chem predicted total acetone columns in August 2016 and February 2017, as well as ATom flight tracks over the ocean. Dashed boxes denote the different oceanic regions roughly based on the oceanic acetone fluxes in Figure 2; the oceanic regions defined based on air-sea exchange of acetone shift with season. A: Northern Hemisphere Pacific $\left(7-60^{\circ} \mathrm{N}\right.$ for ATom- 1 and ATom-2). B: Tropical Pacific $\left(7^{\circ} \mathrm{N}\right.$ to $5^{\circ} \mathrm{S}$ for ATom- 1 and $7^{\circ} \mathrm{N}$ to $18^{\circ} \mathrm{S}$ for

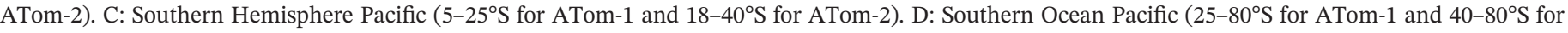
ATom-2). E: Northern Hemisphere Atlantic $\left(7-65^{\circ} \mathrm{N}\right.$ for ATom- 1 and $20-65^{\circ} \mathrm{N}$ for ATom-2). F: Tropical Atlantic $\left(7^{\circ} \mathrm{N}\right.$ to $10^{\circ} \mathrm{S}$ for ATom- 1 and $20^{\circ} \mathrm{N}$ to $10^{\circ} \mathrm{S}$ for ATom-2). G: Southern Hemisphere Atlantic ( $10-40^{\circ} \mathrm{S}$ for ATom- 1 and ATom-2). H: Southern Ocean Atlantic (40-80 ${ }^{\circ} \mathrm{S}$ for ATom- 1 and ATom-2).

vertical profiles are shown in Figure 4 (ATom-1) and Figure 5 (ATom-2). During ATom-1 and ATom-2, both $\mathrm{OH}$ radicals and the photolysis frequency of acetone are well captured by the models (Figure S3).

\subsection{ATom-1: July-August 2016}

During ATom-1 (July-August 2016), the acetone observations over the remote Pacific and Atlantic Oceans show remarkable spatial variation, with maximum acetone mixing ratio as high as $\sim 2.4 \mathrm{ppb}$ in the remote atmosphere. We now elaborate the observations and modeling results in different regions:

i Over the Northern Hemispheric Pacific and Atlantic, observed acetone levels span a wide range, with peak values as high as $\sim 2.4 \mathrm{ppb}$. This is mainly due to the elevated acetone mixing ratios in the continental outflow from Asia and North America (as indicated by CO, Figure S4). CAM-chem underestimates acetone in the Northern Hemisphere continental outflow by up to a factor of $\sim 2$ (Figures $4 \mathrm{a}$ and $4 \mathrm{e}$ ). $\mathrm{CO}$ is reasonably well captured by CAM-chem over the Northern Hemispheric Pacific but is underestimated by up to $\sim 1 / 3$ over the Northern Hemispheric Atlantic (Figures S4a and S4e). With or without oceanic acetone fluxes, CAM-chem simulations do not show large discrepancies over the Northern Hemispheric Ocean during the ATom-1 period (Figure 4). GEOS-Chem acetone is in better agreement with observations in the Northern Hemisphere. CAM-chem in this work uses CMIP6 anthropogenic emissions. The CAM-chem results suggest that the CMIP6 emission inventory may underestimate the emissions of acetone and/or its precursors in the Northern Hemisphere. For instance, CAM-chem modeled propane $\left(\mathrm{C}_{3} \mathrm{H}_{8}\right)$, an important precursor of acetone, is a factor of 2.6-5.0 lower than the TOGA measurements in the Northern Hemisphere. Similar model underestimation (CAM-chem) of lower tropospheric acetone was reported in the Northern Hemisphere (Emmons et al., 2020), which is 

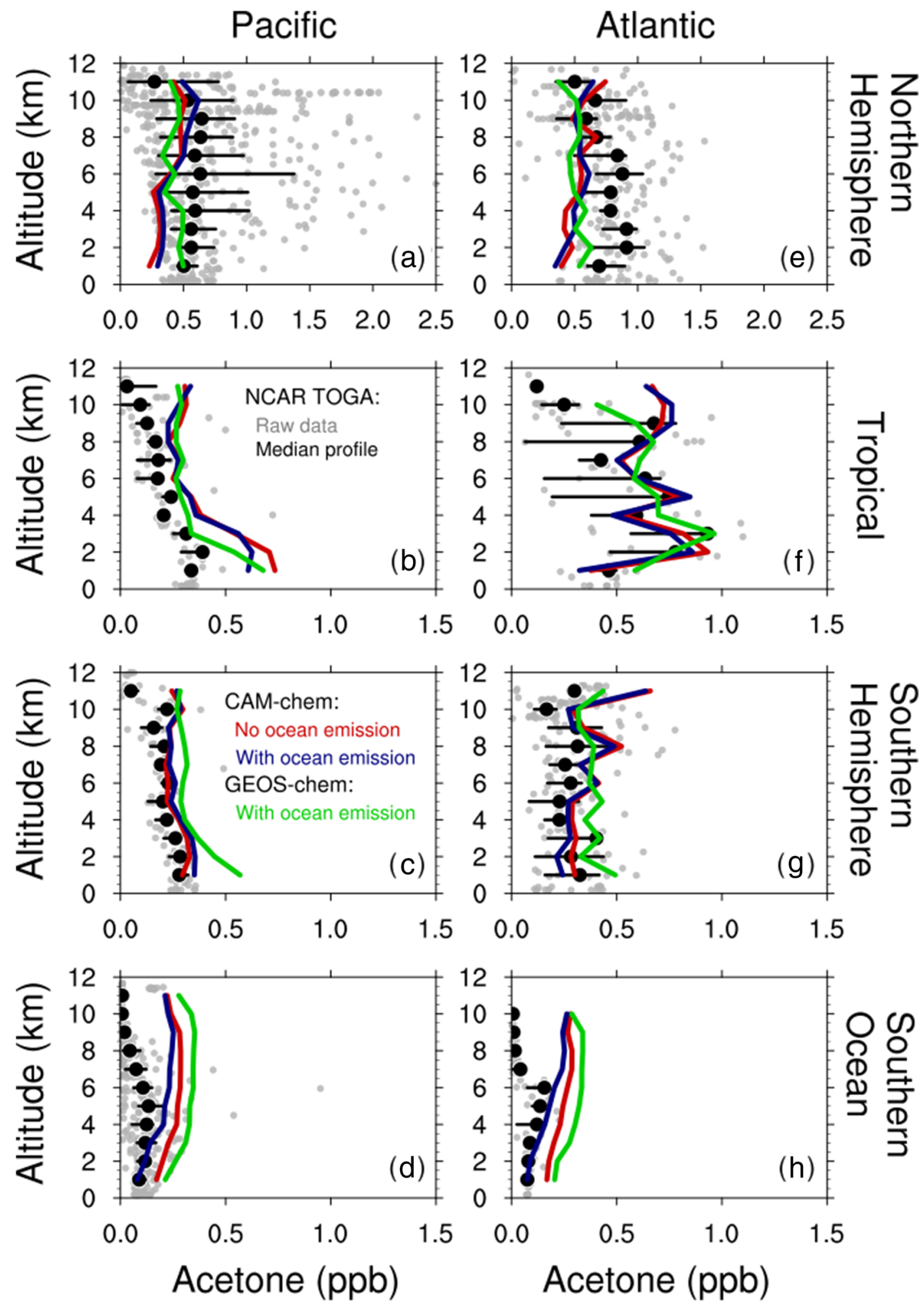

Figure 4. Regional vertical profiles of acetone during ATom-1. Gray points are discreet observations, and black circles and error bars show medians and quartiles of observations. Predicted median model results are shown in red (CAM-chem with no oceanic fluxes), blue (with oceanic fluxes), and green (GEOS-Chem). (a)-(h) represent different regions (Figure 3). 

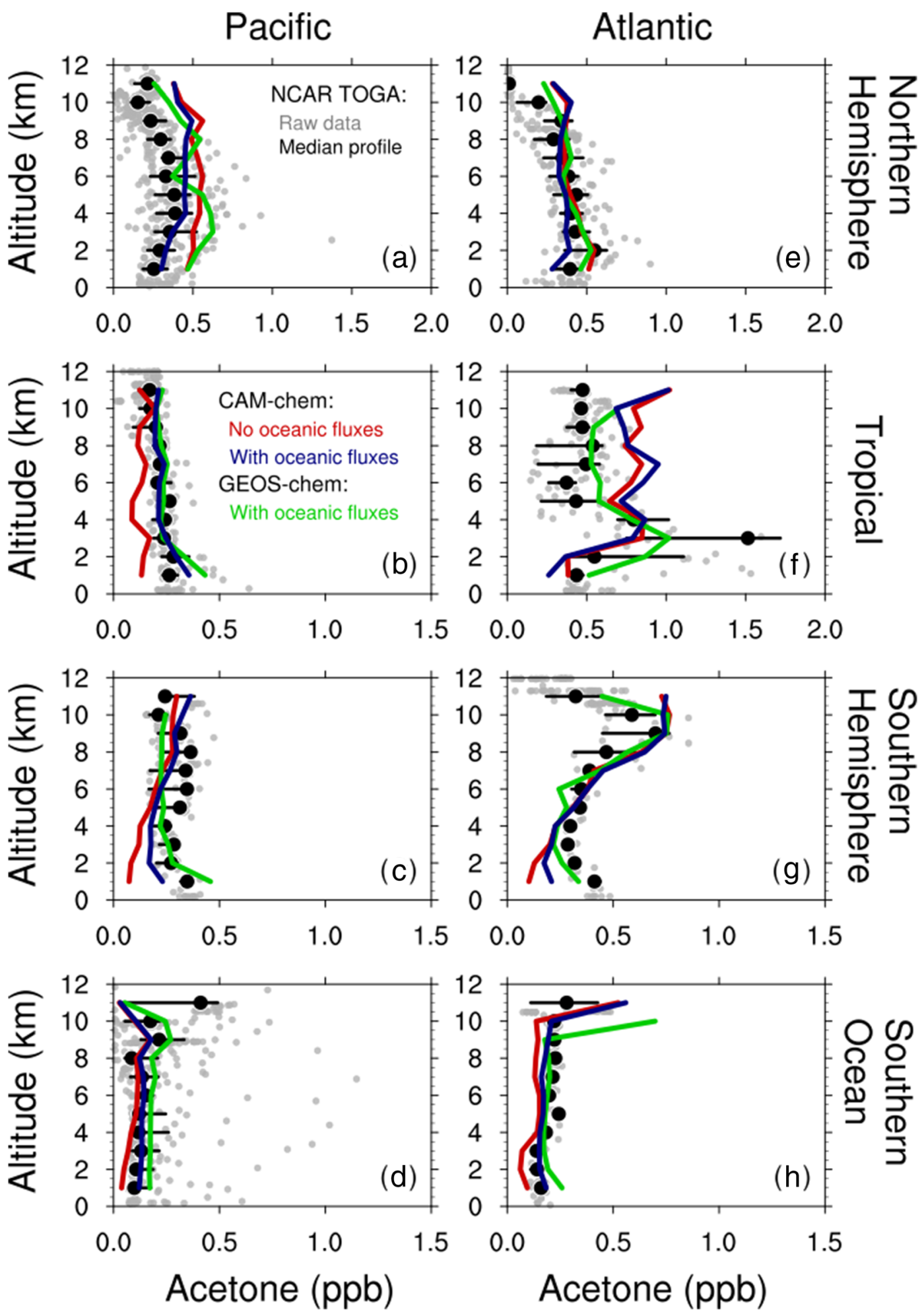

Figure 5. Regional vertical profiles of acetone during ATom-2. Gray points are discreet observations, and black circles and error bars show medians and quartiles of observations. Predicted median model results are shown in red (CAM-chem with no oceanic fluxes), blue (with oceanic fluxes), and green (GEOS-Chem). (a)-(h) represent different regions (Figure 3). 
possibly because of underestimated or unaccounted sources of acetone precursors (such as leakage from the oil/gas industry; Jacob et al., 2002; Pétron et al., 2014). Backward trajectory analysis (https://espo. nasa.gov/atom/archive/browse/atom/DC8/BackTraj) suggests that in August 2016, the low troposphere (below $5 \mathrm{~km}$ ) air masses probed over the Northern Hemispheric Pacific mostly originated from North America and East Asia. The anthropogenic emission inventories of acetone and its precursors show remarkable difference between GEOS-Chem and CAM-chem: GEOS-Chem anthropogenic emissions of propane (EDGAR 4.2, with emissions in certain regions overwritten by regional inventories) is nearly 2 times higher than the anthropogenic emissions of propane used in CAM-chem (CMIP6) in North America and East Asia; GEOS-Chem anthropogenic acetone emissions in North America and East Asia are approximately 11 and 4.6 times higher than CAM-chem, respectively. In light of the model underestimation in the Northern Hemisphere Pacific, a thorough evaluation of the emission inventories in the source regions (especially Asia and North America) is needed, which is beyond the scope of this work since the ATom mission is not aiming at polluted regions.

ii Over the tropical Pacific, both CAM-chem and GEOS-chem overestimate acetone in the marine boundary layer by a factor of $\sim 2$ (Figure $4 \mathrm{~b}$ ). Both models use MEGAN for emissions from the terrestrial ecosystem. As discussed in section 3, a tagged CAM-chem simulation indicated that biogenic acetone contributes substantially in the lower troposphere over the tropical Pacific (Figure S2). CAM-chem with the oceanic acetone fluxes improves acetone predictions in the marine boundary layer (Figure 4b). Therefore, it appears that MEGAN may be overestimating the terrestrial emissions of acetone and/or other precursor BVOCs in the Amazon region.

iii Over the tropical Atlantic, a biomass burning plume from Africa is observed between 2 and $4 \mathrm{~km}$, with $\mathrm{CO}$ up to $\sim 250 \mathrm{ppb}$ (Figure $\mathrm{S} 4 \mathrm{f}$ ) and $\mathrm{HCN}$ and $\mathrm{CH}_{3} \mathrm{CN}$ up to $\sim 1 \mathrm{ppb}$ and $0.5 \mathrm{ppb}$, respectively (HCN and $\mathrm{CH}_{3} \mathrm{CN}$ measurements can be found in Wofsy et al., 2018). Neither CAM-chem nor GEOS-Chem capture the elevated $\mathrm{CO}$ in the biomass burning plume, yet both models can capture the observed acetone vertical profile reasonably well (within the spreads in observations, Figure 4f), implying relatively small biomass burning contribution to the atmospheric acetone or the biomass burning emissions of acetone or of its precursors might be overestimated in the models.

iv Over the Southern Hemispheric Oceans, observed acetone is lower than that in the Northern Hemisphere. GEOS-Chem tends to overestimate acetone in the Southern Hemisphere, while CAM-chem better captures the observed acetone especially in the lower troposphere over the Southern Ocean (Figures 4c, 4d, 4g, and 4h). The overestimate of acetone in GEOS-Chem over the Southern Ocean is likely due to the higher seawater acetone in GEOS-Chem $\left(15 \mathrm{nmol} \mathrm{L}{ }^{-1}\right)$ than that predicted by the machine-learning algorithm $\left(<8 \mathrm{nmol} \mathrm{L}{ }^{-1}\right.$, Figure 1). In general, the Southern Hemisphere, including the Southern Ocean, experience less anthropogenic influences compared to the Northern Hemisphere and hence are more sensitive to natural processes, especially air-sea exchange. The better performance of CAM-chem over this region indicates that the oceanic biogeochemistry control represented by the machine-learning approach provides improved predictability for the CESM model framework. Interestingly, over the Southern Ocean, observed acetone shows clear depletion (<20 ppt) above 5-6 km, while both CAM-chem and GEOS-Chem predict $>300$ ppt acetone in this region (Figures $4 \mathrm{~d}$ and $4 \mathrm{~h}$ ). This will be further explored in section 5.

\subsection{ATom-2: January-February 2017}

During ATom-2, the observed acetone spans a relatively narrower range (up to $\sim 1.5 \mathrm{ppb}$ ) than that during ATom-1. (i) Over the Northern Hemispheric Pacific and Atlantic, observed acetone shows a clear vertical gradient in the marine boundary layer, which increases with increasing altitude. This implies the Northern Hemispheric oceans are a net sink for acetone in boreal winter, consistent with the CAM-chem predicted oceanic acetone fluxes (Figure 2). (ii) Over the tropical Pacific, the ocean is a net source for acetone (Figure 2), and GEOS-Chem and CAM-chem with oceanic acetone fluxes both well capture the acetone vertical profiles. (iii) Over the tropical Atlantic, the aircraft encountered another biomass plume between 1 and $4 \mathrm{~km}$, with CO up to $200 \mathrm{ppb}$ (Figure S5f) and HCN up to 700 ppt. Both models fail to capture the observed acetone and $\mathrm{CO}$ in this biomass burning plume (up to $1.5 \mathrm{ppb}$; Figures $5 \mathrm{f}$ and S4f). (iv) In the Southern Hemisphere, observed acetone in the marine boundary layer decreases with increasing altitude, implying that the Southern Hemispheric oceans in the austral summer are a net source of acetone, consistent with the modeled oceanic acetone fluxes (Figure 2). GEOS-Chem largely captures the observed acetone vertical 
profile over the Southern Hemispheric oceans (Figures $5 \mathrm{c}$ and $5 \mathrm{~g}$ ). CAM-chem without oceanic acetone fluxes underestimates acetone in the lower troposphere by a factor of $\sim 3$; the online oceanic acetone fluxes improve the CAM-chem predictions in the Southern Hemisphere lower troposphere but still fall short of the measurements by a factor of 2 over the Atlantic (Figures $5 \mathrm{c}$ and $5 \mathrm{~g}$ ). Over the Southern Ocean, CAM-chem with oceanic acetone fluxes yields overall best agreement with observations, while GEOS-Chem tends to overestimate acetone in the marine boundary layer (Figures $5 \mathrm{~d}$ and $5 \mathrm{~h}$ ).

To sum up, we use combined observational (TOGA measurements) and modeling (CAM-chem and GEOSChem) analysis to investigate the role of ocean in determining atmospheric acetone abundances over the remote oceans. As discussed above, the role of ocean in the atmospheric budget of acetone shows considerable spatial variation. Globally, the online oceanic acetone fluxes improve CAM-chem acetone predictions in the marine boundary layer $(<2 \mathrm{~km})$, with the mean absolute percentage error reduced from $65 \%$ to $40 \%$ during ATom-1 and 55\% to 30\% during ATom-2, with a mean root square error of 0.14-0.39 ppb (Table S1). GEOS-Chem, using the same oceanic acetone configuration as in Fischer et al. (2012) but with updated isoprene and monoterpene chemistry, produces a mean absolute percentage error of $75 \%$ and $41 \%$ in the marine boundary layer during ATom-1 and ATom-2, respectively, with a mean root square error of 0.15-0.43 ppb (Table S1).

\section{Large Discrepancy Between the Modeled and Measured Acetone Near the Tropopause Over Southern Ocean}

We now come back to the unexpected model-observation discrepancy on acetone above 5-6 km over the Southern Ocean during ATom-1 (Figures 4d and 4h). During these two flights (12 and 15 August 2016), the observed median acetone ranges from 80 to 125 ppt below $5 \mathrm{~km}$, and the CAM-chem modeled acetone ranges from 80 to $185 \mathrm{ppt}$, while GEOS-Chem predicts $>200 \mathrm{ppt}$ throughout (Figures $4 \mathrm{~d}$ and $4 \mathrm{~h}$ ). Above $5 \mathrm{~km}$, the observed median acetone decreases strongly with increasing altitude, from $125 \mathrm{ppt}$ at $5 \mathrm{~km}$ to $<30$ ppt above $8 \mathrm{~km}$. Both models fail to capture the observed altitude dependency above $5 \mathrm{~km}$, consistently predicting $>200 \mathrm{ppt}$ acetone in this region. The model-measurements discrepancy is further shown in the interpolated curtains in Figure 6 (and Figure S6): CAM-chem predicts $>180$ ppt acetone that is widespread between $40^{\circ} \mathrm{S}$ and $70^{\circ} \mathrm{S}$, extending from lower troposphere $(2 \mathrm{~km})$ all the way to the lowermost stratosphere $(13 \mathrm{~km})$; yet observed acetone in this region remains below $200 \mathrm{ppt}$. Such acetone overestimation is not seen in the Northern Hemisphere, possibly due to the higher acetone abundance in the Northern Hemisphere. Four reasons may be responsible for the widespread model overestimation of acetone in the Southern Hemisphere in cold seasons: (i) uncertainties in the acetone chemistry (chemical production/removal); (ii) uncertainties in large-scale transport; (iii) overestimation in the source region; and (iv) missing removal processes. We can rule out some of these reasons which are discussed as follows.

\subsection{Uncertainties in the Acetone Chemistry}

Localized acetone production in the model is unlikely to be significant, since the atmosphere over the Southern Ocean remains mostly dark during austral winter, and major acetone precursors remain low in this region. For instance, during ATom-1 above $6 \mathrm{~km}$ over the Southern Ocean, the TOGA measured propane, $i$-butane, and $n$-butane are $31 \pm 12,2.8 \pm 1.2$, and $3.8 \pm 1.6 \mathrm{ppt}$, respectively (limits of detection [LOD]: 20, 0.5, and $1.0 \mathrm{ppt}$ for propane, $i$-butane, and $n$-butane, respectively. Data below LOD are replaced by two thirds of the LOD). $\alpha$-Pinene remains below its LOD $(0.1 \mathrm{ppt})$ at all times. Photochemistry in the atmosphere is a major sink of acetone, including $\mathrm{OH}$ oxidation, photolysis, and reaction with chlorine atoms. The $\mathrm{OH}$ and photolysis sinks of acetone are both well captured by the models (Figures S3, S7, and S8); therefore, $\mathrm{OH}$ oxidation and photolysis appear to be unlikely culprits for the missing acetone depletion in the models. Chlorine oxidation appears to be plausible, as indicated by the unique chemical signature in Figure 7 (TOGA observed $i$-butane/ $n$-butane ratio vs. $i$-butane/propane ratio). Propane and butanes are often coemitted from anthropogenic sources (e.g., oil and gas industry, fuel evaporation, Jacob et al., 2002 and references therein). $i$-Butane and $n$-butane have similar $\mathrm{OH}$ reactivities (within $9 \%$ between 200 and $300 \mathrm{~K}$ ), yet the chlorine reactivity of $n$-butane is $44-46 \%$ higher than that of $i$-butane between 200 and $300 \mathrm{~K}$ (Burkholder et al., 2015). On the contrary, $i$-butane and propane have similar chlorine atom reactivities( $<3 \%$ between 200 and $300 \mathrm{~K}$ ) but very different $\mathrm{OH}$ reactivities (a factor of 2-3.5 between 200 and $300 \mathrm{~K}$ ) (Burkholder et al., 2015). Therefore, if the data points in Figure 7 are spread out horizontally on this 

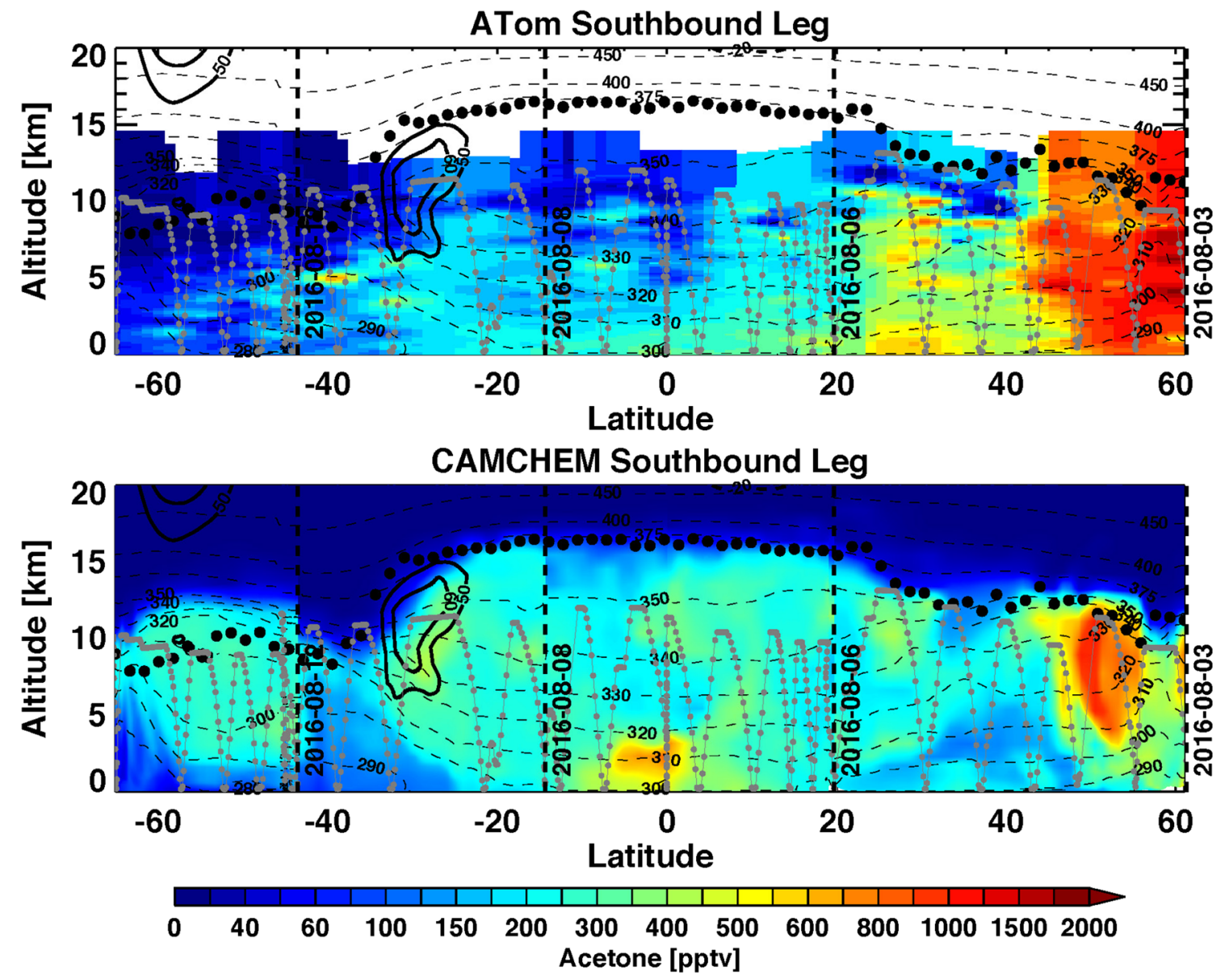

Figure 6. Interpolated meridional curtains of measured (top) and CAM-chem predicted (bottom) acetone during the southbound leg over the Pacific Basin during ATom-1 (corresponding to Regions A-D in Figure 3). The gray dots represent the flight tracks, and the black dots represent the tropopause height. The dashed gray lines denote the isentropes and the heavy black lines denote the jet stream.

ratio-ratio plot, it implies $\mathrm{OH}$ oxidation dominates the aging process of the air mass. However, where the data points are spread vertically, deviating from the horizontal cluster implies a possible influence of chlorine chemistry. Figure 7 implies that, during these two ATom- 1 flights over the Southern Ocean, the observed acetone depletion may be associated with chlorine chemistry signature, or any process that is co-located with chlorine chemistry. Both CAM-chem and GEOS-Chem include the chlorine oxidation of acetone (Burkholder et al., 2015), which cannot explain the acetone depletion observed in the lower stratosphere over the Southern Ocean during ATom-1 due to its slow rate and the low chlorine radical concentrations in the Southern Hemisphere in this season. The tropospheric and stratospheric halogen chemistry in CAM-chem has been evaluated extensively in the literature (Fernandez et al., 2014; Navarro et al., 2015, 2017; Saiz-Lopez \& Fernandez, 2016; Saiz-Lopez \& von Glasow, 2012; Wang, Kinnison, et al., 2019), as has the tropospheric halogen chemistry in GEOS-Chem (Parrella et al., 2012; Schmidt et al., 2016; Sherwen et al., 2016; Wang, Jacob, et al., 2019). A CAM-chem sensitivity test with 100 times faster $\mathrm{Cl}+$ acetone rate coefficient and another 4 year spin-up still cannot explain the observed acetone depletion. Therefore, the chlorine signature as revealed in Figure 7 implies the acetone depletion may be partially related to stratospheric processes (where chlorine chemistry is active), but is unlikely to be due to direct chlorine oxidation of acetone. To sum up, the combined observational and modeling analysis implies that the persistent model overestimation of acetone in this region is unlikely to be due to uncertainties in modeled photochemistry. 


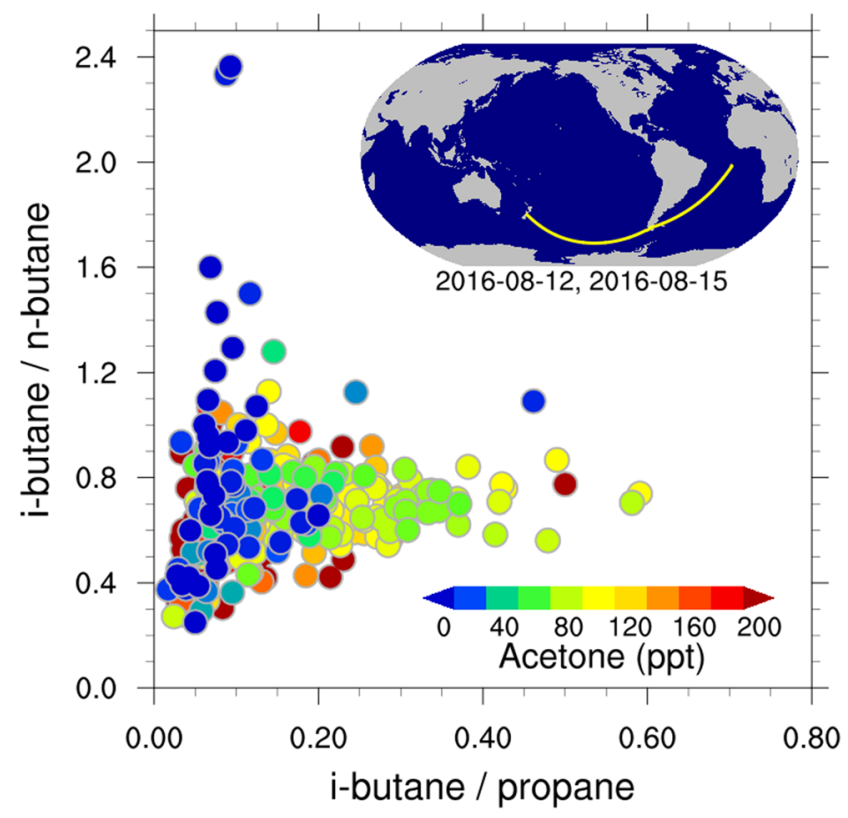

Figure 7. TOGA measured $i$-butane/ $n$-butane ratio versus $i$-butane/ propane ratio during the flights over the Southern Ocean during ATom-1.

\subsection{Uncertainties in the Large-Scale Transport}

During austral winters, the southern high-latitude air mass in the upper troposphere is influenced by the interplay of two large-scale processes. One is the downward transport from the stratosphere driven by the season's strong polar vortex descent, and the other is the isentropic mixing from low latitudes driven by the poleward Rossby wave breaking. To examine the model representation of transport and large-scale circulation, two specific diagnostics were performed, and the results are shown in Figure 8 (also Figures S7 and S8) and an animation in the supporting material (Movie S1).

Figure 8 shows a diagnostic of troposphere-stratosphere transition using tracer-tracer relationship. The $\mathrm{O}_{3}-\mathrm{CO}$ and $\mathrm{O}_{3}-\mathrm{H}_{2} \mathrm{O}$ relationships are most commonly used pairs (Hoor et al., 2002; Pan et al., 2004, 2007). The stratosphere-influenced air (i.e., a mixture of tropospheric air and subsiding stratospheric air) sampled by the aircraft is characterized by elevated $\mathrm{O}_{3}(\sim 100 \mathrm{ppb})$ and low water vapor $\left(\mathrm{H}_{2} \mathrm{O}<40 \mathrm{ppm}\right)$. Figure 8 (Figures S7 and S8) shows that CAM-chem reproduced the observed relationships between the stratospheric tracer $\left(\mathrm{O}_{3}\right)$ and tropospheric tracers $\left(\mathrm{H}_{2} \mathrm{O}\right.$ and $\left.\mathrm{CO}\right)$ which demonstrate the overall good model representation of the large-scale circulation. The stratosphere-influenced air (200$280 \mathrm{hPa}$ ) probed during these two flights contains 45-65 ppb CO, consistent with the $\mathrm{CO}$ measurements reported in the lowermost stratosphere but certainly toward the upper end (de Reus et al., 2003). The tropopause locations and the structures are also reasonably well captured by the CAM-chem (Figure S7 and S8). The modeled and observed acetone versus $\mathrm{O}_{3} / \mathrm{CO}$ relationships, on the other hand, are drastically different in the tropopause region (Figure 8). $\mathrm{CO}$, $\mathrm{O}_{3}$, and $\mathrm{H}_{2} \mathrm{O}$ in this region are reasonably well captured by the models (Figure 8, Figures S4d, S4h, S7, and S8), indicating that the large-scale circulation (Brewer-Dobson circulation) are well represented by the model, and hence the model overestimate of acetone is unlikely due to uncertainties in the model transport or large-scale descent.

Additional diagnostic of large-scale transport from isentropic mixing is shown by CAM-chem models' $\mathrm{O}_{3}$ and acetone evolution on the 310 and $320 \mathrm{~K}$ potential temperature surface for the observation period. As indicated in Figure 6, these isentropes represent the lower troposphere in the subtropics and the tropopause region in the high latitudes. The two animations, using $\mathrm{O}_{3}$ as a transport tracer, highlight the active isentropic transport contribution to the tropopause level acetone in the Southern high latitude from the subtropical lower troposphere. This transport behavior is consistent with the dynamical analysis of the region where active poleward Rossby wave breaking during austral winter was identified (Peters \& Waugh, 2003). These wave-breaking activities are responsible for trace gas transport to the tropopause region as indicated by the low PV streamers (Movies S1 and S2).

The two diagnostics remove the model deficiency of representing large-scale transport as the cause for acetone high bias in the southern high-latitude UTLS (upper troposphere/lower stratosphere). The result, however, pointed out that the isentropic mixing is responsible for modeled high acetone in the tropopause region, indicating either the overrepresentation of subtropical acetone source or the missing removal processes in the cold polar tropopause region are the directions of further investigation.

Acetone measurements in the upper troposphere/lower stratosphere have been reported in the literature (Arnold et al., 1986; Singh et al., 2000); generally acetone in the stratosphere decreases strongly with increasing ozone (Scheeren et al., 2003; Singh, 2004). de Reus et al. (2003) examined the relationship between acetone and $\mathrm{CO}$ for a number of air mass types in a number of airborne campaigns and found systematically lower acetone/CO ratio in the lowermost stratosphere (compared to tropospheric air masses), due to "the increased photolytic loss of acetone and the decreasing $\mathrm{OH}$ concentration with altitude." However, the acetone removal processes near the tropopause has not been quantitatively examined in previous studies, especially in the high-latitude regions during winter. The large discrepancy of modeled and observed acetone in the upper troposphere may imply a currently missing acetone sink in the lower stratosphere, although we 

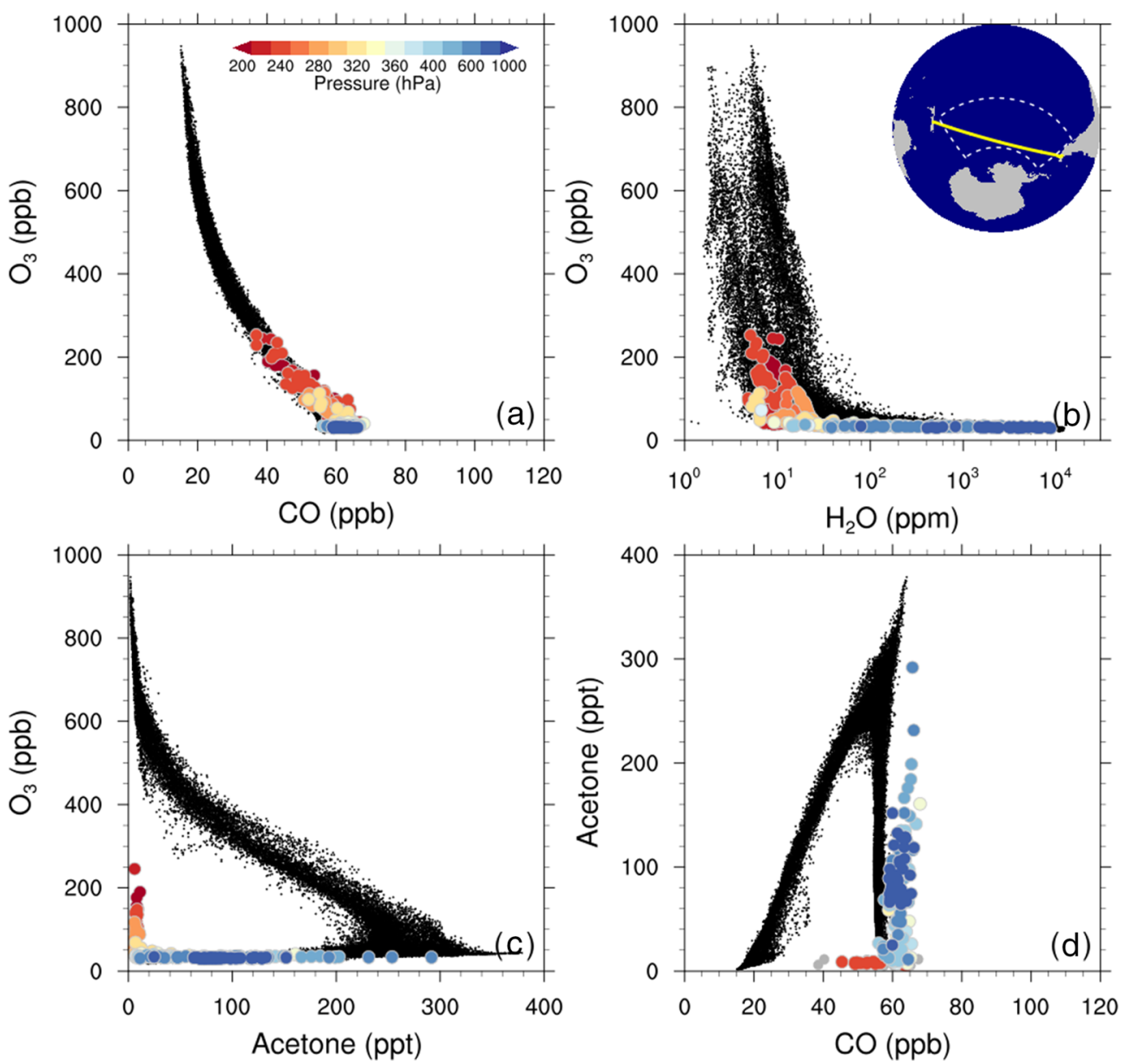

Figure 8. Tracer-tracer relationships over the Southern Ocean Pacific during 12 August 2016: (a) $\mathrm{O}_{3}$ versus $\mathrm{CO}$; (b) $\mathrm{O}_{3}$ versus $\mathrm{H}_{2} \mathrm{O}$; (c) $\mathrm{O}_{3}$ versus acetone; and (d) acetone versus CO. airborne observations are shown as filled circles, color coded by the pressure altitude (tropopause: $\sim 330 \mathrm{hPa}$ ). Flight track is given as a solid line in the embedded map in Panel (b). CAM-chem modeling results are shown as black dots. Note that CAM-chem modeling results in this figure are sampled in the dashed region in the embedded map, not along the flight track.

cannot rule out the possibility that acetone may be overestimated in the source regions, which will be elaborated in the following section.

\subsection{Acetone Overestimation in the Source Regions}

As shown in Figures 6 and S6 and Movie S1, the rapid isentropic transport connects the tropical/subtropical regions with the high-latitude regions. Therefore, we identify the tropical/subtropical $\left(20^{\circ} \mathrm{S}\right.$ to equator) midtroposphere/upper troposphere (5-12 km) as the potential source regions of the upper troposphere over the Southern Ocean, where large model-measurement disagreement is observed. Although the large-scale circulation and transport is well capture by the models (section 5.2), any overestimation of acetone in the source region may lead to an overestimation of acetone in the upper troposphere/lower stratosphere in the high-latitude regions. As shown in Figure 6, the observed acetone level in the tropical/subtropical midtroposphere/upper troposphere (150-350 ppt) over the Pacific Basin are only slightly overestimated by CAM-chem (200-450 ppt); however, Figure S6 shows that CAM-chem overestimates acetone in the subtropical midtroposphere over the Atlantic Basin (500-900 ppt) relative to observations (400-600 ppt). It appears that acetone is indeed overestimated in the source regions. The driver of the acetone overestimation in the source regions, and the degree to which such overestimation in the lower latitude regions affect the acetone transport and accumulation in the high-latitude regions, will be investigated in a separate work. 


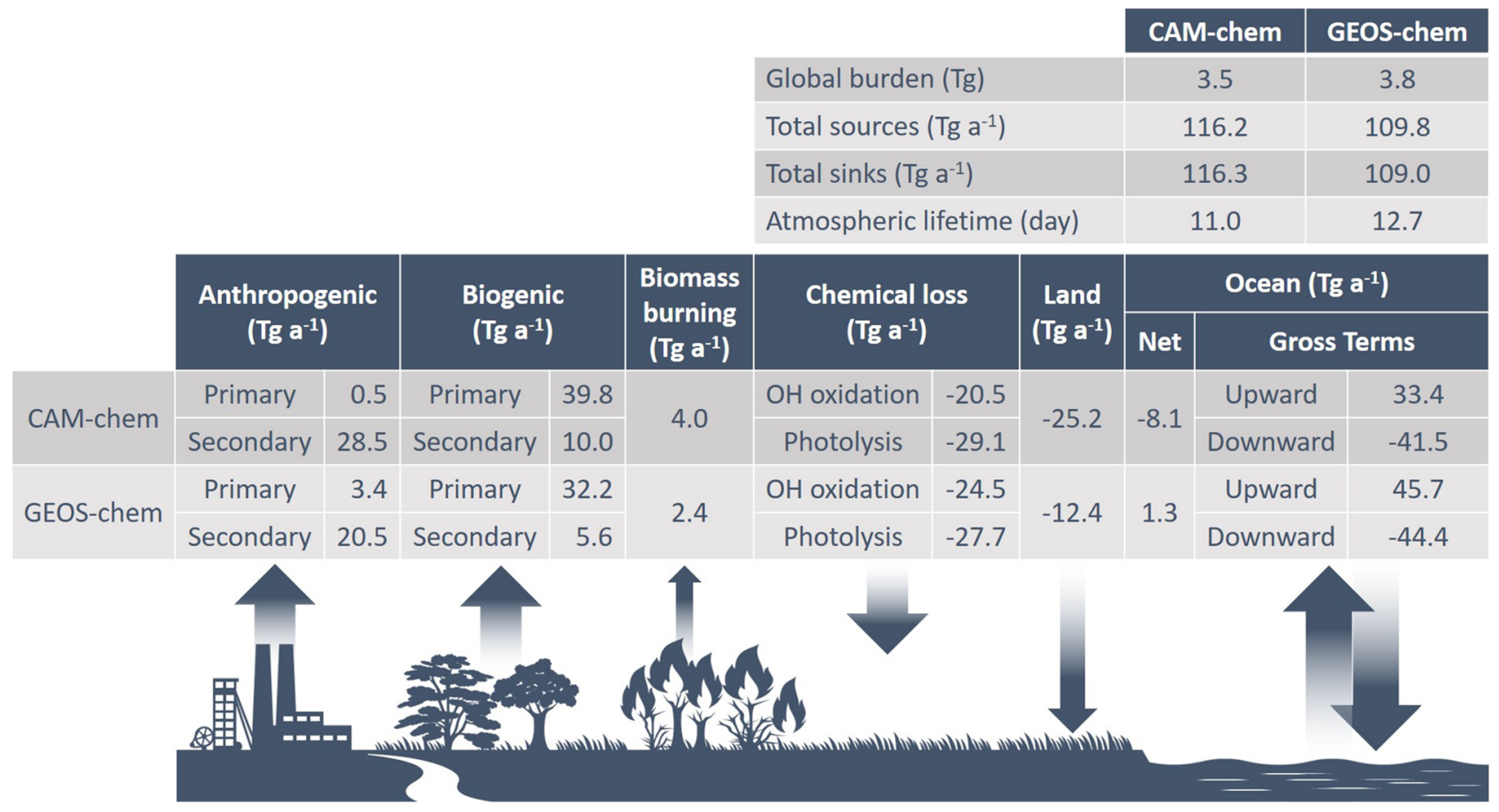

Figure 9. The global budget of acetone, as well as the global burden and the atmospheric lifetime of acetone, calculated by CAM-chem and GEOS-Chem. In the bottom budget table, positive and negative values denote atmospheric source and sink terms, respectively. CAM-chem secondary anthropogenic source includes $7.6 \mathrm{Tg} \mathrm{a}^{-1}$ from propane, $13.3 \mathrm{Tg} \mathrm{a}^{-1}$ from BIGALK ( $\mathrm{C}_{4}$ and larger alkanes), and $7.6 \mathrm{Tg} \mathrm{a}^{-1}$ from BIGENE ( $\mathrm{C}_{4}$ and larger alkenes). CAM-chem secondary biogenic source includes $5.8 \mathrm{Tg} \mathrm{a}^{-1}$ from $\alpha$-pinene, $0.3 \mathrm{Tg} \mathrm{a}^{-1}$ from $\beta$-pinene, and $3.9 \mathrm{Tg} \mathrm{a}^{-1}$ from myrcene. GEOS-Chem secondary anthropogenic source includes $14.2 \mathrm{Tg} \mathrm{a}^{-1}$ from propane and $6.3 \mathrm{Tg} \mathrm{a}^{-1}$ from ALK4 ( $\mathrm{C}_{4}$ and larger alkanes). The GEOS-Chem secondary biogenic source is from unspeciated terpenes. Gross oceanic emissions/uptake are considered in the total sources/sinks.

To sum up, the large discrepancy of modeled and observed acetone in the upper troposphere/lower stratosphere over the Southern Ocean is unlikely due to known photochemistry or large-scale transport but likely due to currently missing removal processes or acetone overestimation in the tropical/subtropical troposphere. Notably, this is not an episodic event. We have examined WACCM model (similar to CAM-chem but extends in altitude to the lower thermosphere) outputs for previous years, and the meridional curtains always show similar acetone "hot spots" in this region during austral winter. Similar results are consistently seen in GEOS-Chem, and the atmospheric component of the Geophysical Fluid Dynamics Laboratory coupled model (GFDL AM4.1, V. Naik and J. He, NOAA/GFDL, personal communication, December 2019), despite the very different treatment of chemistry and physics among these models. The impacts of such model high bias remain unclear and will be further investigated in a separated manuscript. However, the high model bias is unlikely to affect the $\mathrm{HO}_{x}$ budget over the Southern Ocean, since acetone contributes to $\mathrm{HO}_{x}$ production mainly in the tropics and subtropics (section 7).

\section{Global Budget of Acetone}

The global atmospheric budget of acetone calculated using both CAM-chem and GEOS-Chem is shown in Figure 9. The global burden of acetone calculated by CAM-chem is $3.5 \mathrm{Tg}$, very similar to that calculated using GEOS-Chem (3.8 Tg). The global atmospheric lifetime of acetone against all sinks is estimated to be 11.0 and 12.7 days by CAM-chem and GEOS-Chem, respectively. In this work, we calculate the global atmospheric lifetime of acetone against all its chemical and physical sinks; for the ocean uptake, the gross uptake term is included, consistent with previous studies (Brewer et al., 2017; Fischer et al., 2012). Globally, both CAM-chem and GEOS-Chem predict that biogenic sources are the dominant acetone source, with primary terrestrial emission a factor of $\sim 4-5$ higher than the secondary production from other BVOCs. Anthropogenic emissions contribute 38\% (CAM-chem) and 37\% (GEOS-Chem) of the total acetone source globally, which is dominated by secondary production from alkanes. Biomass burning contributes a small 


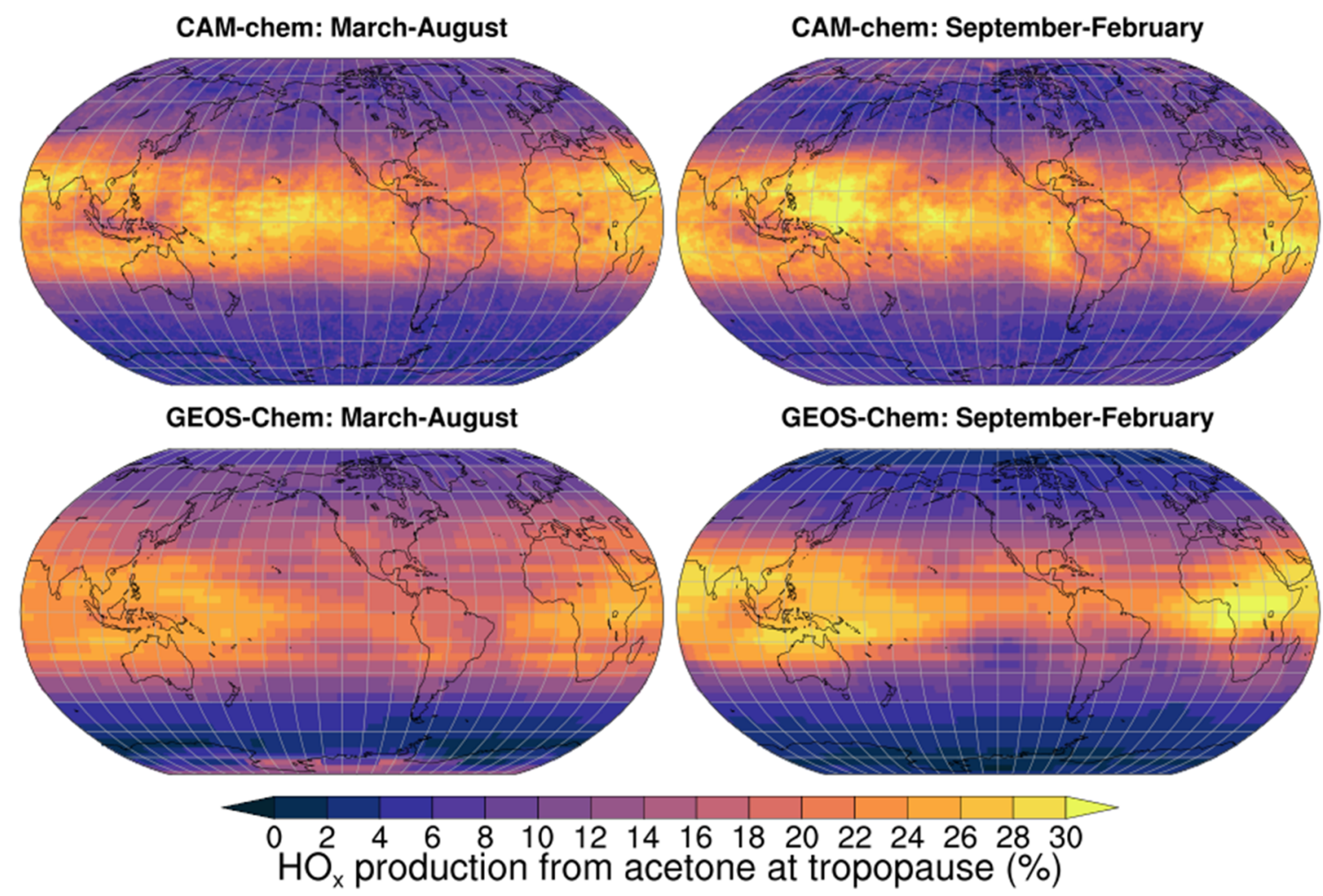

Figure 10. CAM-chem and GEOS-Chem predicted meridional mean curtains of the acetone percent contribution to total $\mathrm{HO}_{x}$ production in $\mathrm{March}-\mathrm{August}$ and September-February.

fraction of atmospheric acetone, yet in certain regions/seasons the biomass burning contribution can be substantial (Figure 4 and Figure 5). Photochemical loss is the major acetone sink, and both CAM-chem and GEOS-Chem predict that photolysis contributes to more acetone loss than $\mathrm{OH}$ oxidation. Recent GEOS-Chem studies report an opposite trend: for instance, Brewer et al. (2017) and Fischer et al. (2012) both suggest $\mathrm{OH}$ oxidation is the major sink of acetone. Another recent study (Khan et al., 2015) reports that $\mathrm{OH}$ oxidation and photolysis are equally important for acetone removal. The pressure-/temperaturedependent acetone photolysis (Blitz et al., 2004) was not available in early studies (e.g., Jacob et al., 2002), leading to potential overestimate of photolysis contribution. Terrestrial uptake over land shows a factor of $\sim 2$ discrepancy between the two models. In CAM-chem, both dry deposition and wet deposition are considered for acetone, with dry deposition contributing to over $98 \%$ of the total deposition. GEOS-Chem does not have wet deposition for acetone. CAM-chem online calculates dry deposition velocity $\left(V_{\mathrm{d}}\right)$ of acetone for different surface types. For example, the mean $V_{\mathrm{d}}$ is $0.008 \mathrm{~cm} \mathrm{~s}^{-1}$ for bare ground/nonvegetation surface (leaf area index, LAI $=0$ ); $0.18 \mathrm{~cm} \mathrm{~s}^{-1}$ for LAI between 0 and 1; $0.27 \mathrm{~cm} \mathrm{~s}^{-1}$ for LAI larger than 2. Using the surface-dependent dry deposition velocity of acetone, CAM-chem predicts that the South America (mostly Amazon region) alone accounts for 36\% of the global acetone dry deposition. GEOS-Chem uses a fixed dry deposition velocity of $0.1 \mathrm{~cm} \mathrm{~s}^{-1}$ for all surface types (Brewer et al., 2017; Fischer et al., 2012). The limited measurements of $V_{\mathrm{d}}$ for acetone range from 0.02 to $0.46 \mathrm{~cm} \mathrm{~s}^{-1}$ (Karl et al., 2004, 2005). Given the large discrepancy between CAM-chem and GEOS-Chem, and the potential importance of dry deposition especially over the forest regions, the dry deposition of acetone warrants further exploration.

On the global scale, the large gross upward (emitting) oceanic fluxes of acetone are more or less balanced by the gross downward (uptaking) oceanic fluxes, implying that the atmosphere-ocean exchange of acetone is close to equilibrium. Using the machine learning-predicted surface seawater acetone concentrations and the updated BVOC chemistry, CAM-chem predicts that the global ocean is a small net sink of acetone $(-8.1 \mathrm{Tg}$ $\mathrm{a}^{-1}$ ), which is the difference between the two large gross terms (upward and downward: 33.4 and $41.5 \mathrm{Tg}$ 
CAM-chem: March-August

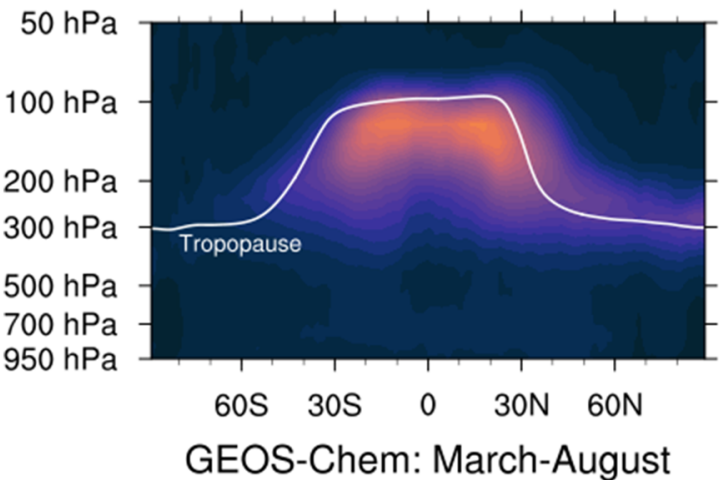

$50 \mathrm{hPa}$
$100 \mathrm{hPa}$
$200 \mathrm{hPa}$
$300 \mathrm{hPa}$
$500 \mathrm{hPa}$
$700 \mathrm{hPa}$
$950 \mathrm{hPa}$
GEOS-Chem: March-August

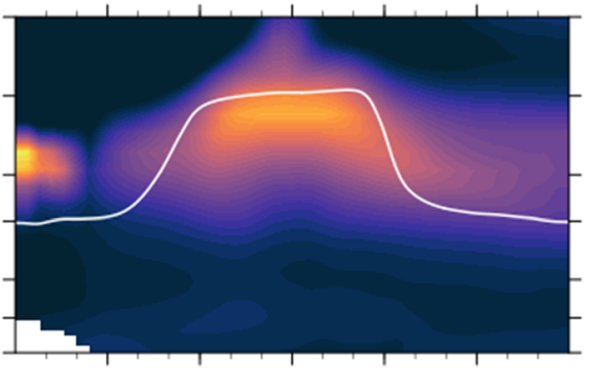

$60 \mathrm{~S}$

$30 \mathrm{~N} 60 \mathrm{~N}$
CAM-chem: September-February

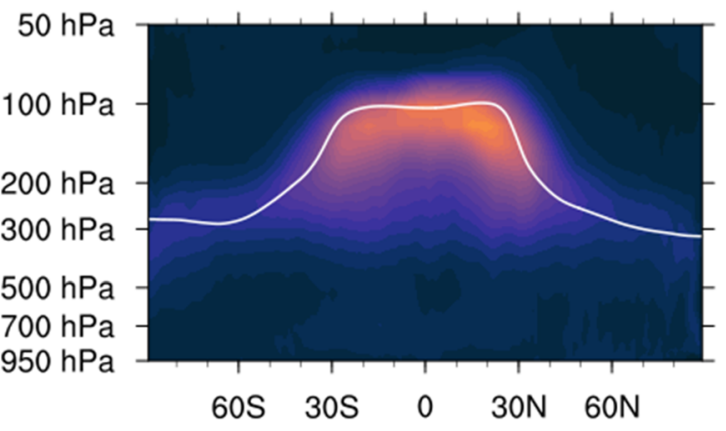

GEOS-Chem: September-February

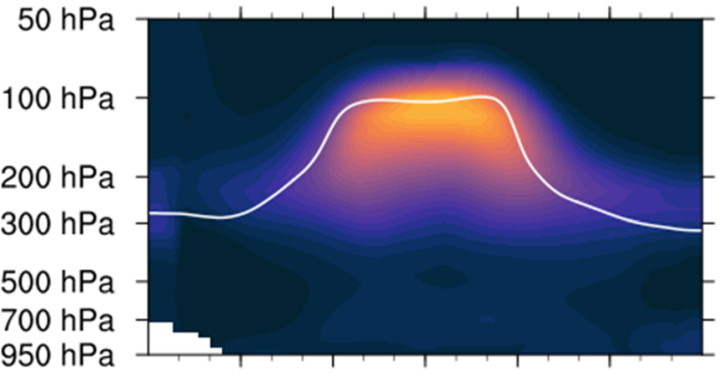

$60 \mathrm{~S} \quad 30 \mathrm{~S} \quad 0 \quad 30 \mathrm{~N} \quad 60 \mathrm{~N}$

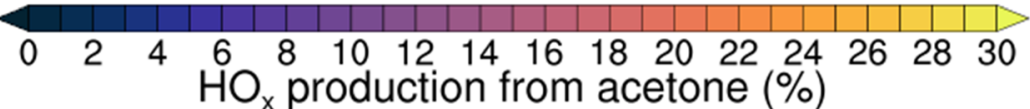

Figure 11. CAM-chem and GEOS-Chem predicted seasonal means of the contribution to the total $\mathrm{HO}_{x}$ production from acetone at the tropopause.

$\mathrm{a}^{-1}$, respectively, Figure 9). GEOS-Chem, with a fixed surface seawater concentration of acetone (15 nM), predicted global gross upward and downward oceanic fluxes are on the same order of magnitude (45.7 and $44.4 \mathrm{Tg} \mathrm{a}^{-1}$, Figure 9), with a very small net emitting tendency from the ocean $\left(+1.3 \mathrm{Tg} \mathrm{a}^{-1}\right)$. We consider the CAM-chem prediction of the ocean net exchange $\left(-8.1 \mathrm{Tg} \mathrm{a}^{-1}\right)$ to be more robust, since the machine-learning approach linked to CAM-chem takes advantages of more recent seawater acetone measurements, leading to an improved agreement with observations in the global marine boundary layer (Table S1). To summarize, both models support the view that the ocean strongly regulates atmospheric acetone abundances, consistent with previous studies (Brewer et al., 2017; Fischer et al., 2012; Jacob et al., 2002).

\section{7. $\mathrm{HO}_{x}$ Production From Acetone}

In this work, acetone contribution to total $\mathrm{HO}_{x}$ production is calculated by counting the difference between simulated $\mathrm{HO}_{x}$ in a base case scenario (as shown in Figures 3-5) and the simulated $\mathrm{HO}_{x}$ when acetone is allowed to undergo chemical removal without $\mathrm{HO}_{x}$ radical production. This approach accounts for the total $\mathrm{HO}_{x}$ production from acetone oxidation products (mainly $\mathrm{CH}_{3} \mathrm{O}_{2}$ and $\mathrm{CH}_{3} \mathrm{CO}_{3}$ ), which depends on $\mathrm{NO}_{x}$, several photolysis channels and cycling pathways. As shown in Figure 10, the acetone contribution to total $\mathrm{HO}_{x}$ production peaks in the tropical and subtropical upper troposphere and the lowermost stratosphere, contributing up to $24 \%$ in CAM-chem and $27 \%$ in GEOS-Chem (both meridional means). The acetone contribution to $\mathrm{HO}_{x}$ production peaks in the tropical and subtropical upper troposphere and lowermost stratosphere, where the $\mathrm{O}_{3}-\mathrm{O}\left({ }^{1} \mathrm{D}\right)-\mathrm{H}_{2} \mathrm{O}$ mechanism is less efficient due to the dehydration associated with updrafts. The acetone contribution to $\mathrm{HO}_{x}$ production decreases substantially in the middle- and high-latitude regions. GEOS-Chem predicts higher acetone-induced $\mathrm{HO}_{x}$ production in the Northern Hemisphere in summer (Figure 10), due to the higher acetone abundance predicted by GEOS-Chem over 
this region (Figure 3). The sharp latitude gradient is also visible in Figure 11, which shows the seasonal means of the acetone-induced $\mathrm{HO}_{x}$ production at the tropopause. Figure 10 shows that near the tropopause over the Western tropical Pacific, acetone contributes to $35-40 \% \mathrm{HO}_{x}$ production year long. Between September and February, the contribution of acetone to $\mathrm{HO}_{x}$ production near the tropopause reaches $\sim 40 \%$ over Africa. Between March and August however, the contribution of acetone to $\mathrm{HO}_{x}$ production reaches $\sim 36 \%$ over South Asia/Indian Ocean, Northern Africa and Western Asia. Note that the acetone contribution to the total $\mathrm{HO}_{x}$ production estimated in this work may be potentially biased, since the possible contributions of higher aldehydes (Müller \& Brasseur, 1999; Wennberg et al., 1998) may not be captured by the models in the remote atmosphere. Recently, Neumaier et al. (2014) estimated the acetone contribution to $\mathrm{HO}_{x}$ production in the upper troposphere and lower stratosphere using airborne observations, and reported that acetone-induced $\mathrm{HO}_{x}$ production can be 61-95\% of the $\mathrm{HO}_{x}$ production from ozone (note that other $\mathrm{HO}_{x}$ sources, such as formaldehyde, are not considered in Neumaier et al.). Assuming 4\% $\mathrm{HO}_{x}$ production from formaldehyde (Nicely et al., 2016), the results in Neumaier et al. (2014) imply an acetone-induced $\mathrm{HO}_{x}$ production of up to $36-47 \%$, generally consistent with the estimate in this work (Figures 10 and 11).

\section{Conclusions}

We report the global atmospheric budget of acetone calculated using two global models, CAM-chem and GEOS-Chem, and the models are compared to observations from a recent global-scale, multiseasonal airborne campaign, NASA ATom. Both CAM-chem and GEOS-Chem include updated BVOC chemical mechanisms. CAM-chem is equipped with an online air-sea exchange model framework to calculate the bidirectional oceanic fluxes of acetone. The surface seawater concentrations of acetone are predicted using a data-oriented machine-learning algorithm. We show that the ocean strongly regulates the acetone budget over the remote oceans. The machine-learning algorithm captures the large-scale features revealed in the limited surface seawater observations. Generally, there is very sparse availability of surface seawater concentration and flux measurements for acetone, especially in the Pacific Ocean, Indian Ocean, and Southern Ocean, and future ship-based studies should target these regions. We show that together the online air-sea exchange framework and the observationally trained machine-learning approach show promising potential. The performance can be further improved when more measurements become available. This model framework can be expanded to the marine emissions for other climate-relevant gases, such as dimethyl sulfide (DMS).

We show that the newly developed marine acetone inventory, with the ocean biogeochemistry control represented by a machine-learning approach, results in improved agreement with observations in the remote marine boundary layer, such as in the Southern Hemisphere and the Southern Ocean. Both CAM-chem and GEOS-Chem capture measured acetone vertical distributions in the remote troposphere reasonably well, although the drivers behind some of the observed spatial and seasonal variability remain unclear. Despite different model configurations, the global budget, total atmospheric burden, and the atmospheric lifetime of acetone derived from the two models are quite similar. The combined observational and modeling analysis suggest that (i) the CMIP6 anthropogenic emission inventory may underestimate acetone and/or its precursors in the North Hemisphere. (ii) MEGAN may overestimate acetone and/or its precursor emissions from the terrestrial ecosystem, and/or the biogenic oxidation mechanisms may overestimate secondary acetone yields. (iii) The model overestimation of acetone in the upper troposphere-lower stratosphere in the Southern Hemisphere in winter is unlikely due to photochemistry or transport; the widespread model-measurement discrepancy may imply an unknown acetone removal mechanism or the acetone overestimation in the subtropical midtroposphere.

Lastly, we show that acetone may contribute up to $30-40 \%$ of $\mathrm{HO}_{x}$ production near the tropopause, especially in the tropical regions, where troposphere-stratosphere exchange is active (e.g., strong convective transport or Asian Monsoon). The acetone contribution to $\mathrm{HO}_{x}$ production derived in this work is comparable to previous work (Neumaier et al., 2014). The tropical oceans are also a net source of acetone, leading to stronger ocean biogeochemistry control on the oxidative capacity in the tropical upper troposphere and the lowermost stratosphere. 


\section{Data Availability Statement}

CAM-chem is a component of the NCAR CESM ${ }^{\mathrm{TM}}$ which is publicly available on the project website (http:// www.cesm.ucar.edu/) and github (https://github.com/ESCOMP/CESM). The CESM project is supported primarily by the NSF. GEOS-Chem (https://doi.org/10.5281/zenodo.1343547) is publicly available on github (https://github.com/geoschem/geos-chem). For more details on GEOS-Chem, see the project website (http://acmg.seas.harvard.edu/geos/). This material is based upon work supported by NCAR, which is a major facility sponsored by the NSF under Cooperative Agreement 1852977 . The computing and data storage resources, including the Cheyenne supercomputer (doi:10.5065/D6RX99HX), were provided by the Computational and Information Systems Laboratory (CISL) at NCAR. The Atmospheric Tomography Mission (ATom) is funded by the Earth Science Project Office at NASA (NNX15AJ23G). The NCAR TOGA and other airborne measurements obtained during the NASA ATom campaign are available from Wofsy et al. (2018), accessed on 18 September 2019. The surface seawater acetone climatology data product is available from Wang et al. (2020).

\section{Acknowledgments}

S.-Y. W. is partially supported by the NCAR Advanced Study Program (ASP) Postdoctoral Fellowship. K. H. B. acknowledges support from the National Oceanic and Atmospheric Administration (NOAA)'s Climate and Global Change Fellowship program. Support for E. V. F. was provided by NASA Grant NNX16AI17G. Work at Harvard (K. H. B. and D. J. J.) was supported by the Atmospheric Chemistry Program of the US National Science Foundation (NSF). We thank NASA ESPO, the NASA DC- 8 crew, and the ATom Science Team for their exceptional professionalism in support of this mission. We thank Dr. Vaishali Naik and Dr. Jian He (NOAA/GFDL) for sharing the GFDM AM4.1 modeling outputs, and three reviewers for the constructive comments.

\section{References}

Apel, E., Hornbrook, R. S., Hills, A. J., Blake, N. J., Barth, M. C., Weinheimer, A., et al. (2015). Upper tropospheric ozone production from lightning $\mathrm{NO}_{x}$-impacted convection: Smoke ingestion case study from the DC3 campaign. Journal of Geophysical Research: Atmospheres, 120, 2505-2523. https://doi.org/10.1002/2014JD022121

Apel, E. C., Hills, A. J., Leub, R., Zindel, S., Eisele, S., \& Riemer, D. D. (2003). A fast-GC/MS system to measure $\mathrm{C}_{2}$ to $\mathrm{C}_{4} \mathrm{carbonyls}$ and methanol aboard aircraft. Journal of Geophysical Research, 108(D20), 8794. https://doi.org/10.1029/2002JD003199

Arnold, F., Bürger, V., Droste-Fanke, B., Grimm, F., Krieger, A., Schneider, J., \& Stilp, T. (1997). Acetone in the upper troposphere and lower stratosphere: Impact on trace gases and aerosols. Geophysical Research Letters, 24(23), 3017-3020. https://doi.org/10.1029/97GL02974

Arnold, F., Knop, G., \& Ziereis, H. (1986). Acetone measurements in the upper troposphere and lower stratosphere-Implications for hydroxyl radical abundances. Nature, 321(6069), 505-507. https://doi.org/10.1038/321505a0

Atkinson, R., \& Arey, J. (2003). Gas-phase tropospheric chemistry of biogenic volatile organic compounds: A review. Atmospheric Environment, 37(supplement 2), 197-219.

Bates, K. H., \& Jacob, D. J. (2019). A new model mechanism for atmospheric oxidation of isoprene: Global effects on oxidants, nitrogen oxides, organic products, and secondary organic aerosol. Atmospheric Chemistry and Physics, 19(14), 9613-9640. https://doi.org/10.5194/ acp-19-9613-2019

Beale, R., Dixon, J., Arnold, S., Liss, P., \& Nightingale, P. (2013). Methanol, acetaldehyde, and acetone in the surface waters of the Atlantic Ocean. Journal of Geophysical Research: Oceans, 118, 5412-5425. https://doi.org/10.1002/jgrc.20322

Blitz, M., Heard, D. E., Pilling, M. J., Arnold, S. R., \& Chipperfield, M. P. (2004). Pressure and temperature-dependent quantum yields for the photodissociation of acetone between 279 and $327.5 \mathrm{~nm}$. Geophysical Research Letters, 31, L06111. https://doi.org/10.1029/ 2003GL018793

Breiman, L. (2001). Random forests. Machine Learning, 45(1), 5-32. https://doi.org/10.1023/A:1010933404324

Brewer, J. F., Bishop, M., Kelp, M., Keller, C. A., Ravishankara, A. R., \& Fischer, E. V. (2017). A sensitivity analysis of key natural factors in the modeled global acetone budget. Journal of Geophysical Research: Atmospheres, 122, 2043-2058. https://doi.org/10.1002/ 2016JD025935

Burkholder, J. B., Sander, S. P., Abbatt, J., Barker, J. R., Huie, R. E., Kolb, C. E., et al. (2015). Chemical kinetics and photochemical data for use in atmospheric studies, evaluation no. 18. JPL Publication 10-6, Jet Propulsion Laboratory, Pasadena

Carpenter, L. J., \& Nightingale, P. D. (2015). Chemistry and release of gases from the surface ocean. Chemical Reviews, 115(10), 4015-4034. https://doi.org/10.1021/cr5007123

Crosson, E. R. (2008). A cavity ring-down analyzer for measuring atmospheric levels of methane, carbon dioxide, and water vapor. Applied Physics B, 92(3), 403-408. https://doi.org/10.1007/s00340-008-3135-y

de Reus, M., Fischer, H., Arnold, F., de Gouw, J., Holzinger, R., Warneke, C., \& Williams, J. (2003). On the relationship between acetone and carbon monoxide in different air masses. Atmospheric Chemistry and Physics, 3(5), 1709-1723. https://doi.org/10.5194/acp-3-1709-2003

Diskin, G. S., Podolske, J. R., Sachse, G. W., \& Slate, T. A. (2002). Open-path airborne tunable diode laser hygrometer. Proc. SPIE 4817 (Vol. 4817, pp. 4817-4819). Diode Lasers and Applications in Atmospheric Sensing. https://doi.org/10.1117/12.453736

Dixon, J., Beale, R., \& Nightingale, P. (2013). Production of methanol, acetaldehyde, and acetone in the Atlantic Ocean. Geophysical Research Letters, 40, 4700-4705. https://doi.org/10.1002/grl.50922

Dixon, J. L., Beale, R., Sargeant, S. L., Tarran, G. A., \& Nightingale, P. D. (2014). Microbial acetone oxidation in coastal seawater. Frontiers in Microbiology, 5. https://doi.org/10.3389/fmicb.2014.00243

Emmons, L. K., Schwantes, R. H., Orlando, J. J., Tyndall, G., Kinnison, D., Lamarque, J.-F., et al. (2020). The chemistry mechanism in the Community Earth System Model Version 2 (CESM2). Journal of Advances in Modeling Earth Systems, 12. https://doi.org/10.1029/ 2019MS001882

Faloona, I. C., Tan, D., Lesher, R. L., Hazen, N. L., Frame, C. L., Simpas, J. B., et al. (2004). A laser-induced fluorescence instrument for detecting tropospheric $\mathrm{OH}$ and $\mathrm{HO}_{2}$ : Characteristics and calibration. Journal of Atmospheric Chemistry, 47(2), 139-167. https://doi.org/ 10.1023/B:JOCH.0000021036.53185.0e

Fernandez, R. P., Salawitch, R. J., Kinnison, D. E., Lamarque, J. F., \& Saiz-Lopez, A. (2014). Bromine partitioning in the tropical tropopause layer: Implications for stratospheric injection. Atmospheric Chemistry and Physics, 14(24), 13,391-13,410. https://doi.org/10.5194/acp14-13391-2014

Fischer, E. V., Jacob, D. J., Millet, D. B., Yantosca, R. M., \& Mao, J. (2012). The role of the ocean in the global atmospheric budget of acetone. Geophysical Research Letters, 39, L01807. https://doi.org/10.1029/2011GL050086

Fischer, E. V., Jacob, D. J., Yantosca, R. M., Sulprizio, M. P., Millet, D. B., Mao, J., et al. (2014). Atmospheric peroxyacetyl nitrate (PAN): A global budget and source attribution. Atmospheric Chemistry and Physics, 14(5), 2679-2698. https://doi.org/10.5194/acp-14-2679-2014 
Fisher, J. A., Jacob, D. J., Travis, K. R., Kim, P. S., Marais, E. A., Chan Miller, C., et al. (2016). Organic nitrate chemistry and its implications for nitrogen budgets in an isoprene- and monoterpene-rich atmosphere: Constraints from aircraft (SEAC ${ }^{4} \mathrm{RS}$ ) and ground-based (SOAS) observations in the southeast US. Atmospheric Chemistry and Physics, 16(9), 5969-5991. https://doi.org/10.5194/acp-16-5969-2016

Franco, B., Clarisse, L., Stavrakou, T., Müller, J.-F., Pozzer, A., Hadji-Lazaro, J., et al. (2019). Acetone atmospheric distribution retrieved from space. Geophysical Research Letters, 46, 2884-2893. https://doi.org/10.1029/2019GL082052

Guenther, A. B., Jiang, X., Heald, C. L., Sakulyanontvittaya, T., Duhl, T., Emmons, L. K., \& Wang, X. (2012). The Model of Emissions of Gases and Aerosols from Nature version 2.1 (MEGAN2.1): An extended and updated framework for modeling biogenic emissions. Geoscientific Model Development, 5(6), 1471-1492. https://doi.org/10.5194/gmd-5-1471-2012

Hoesly, R. M., Smith, S. J., Feng, L., Klimont, Z., Janssens-Maenhout, G., Pitkanen, T., et al. (2018). Historical (1750-2014) anthropogenic emissions of reactive gases and aerosols from the Community Emissions Data System (CEDS). Geoscientific Model Development, 11(1), 369-408. https://doi.org/10.5194/gmd-11-369-2018

Holzinger, R., Warneke, C., Hansel, A., Jordan, A., Lindinger, W., Scharffe, D. H., et al. (1999). Biomass burning as a source of formaldehyde, acetaldehyde, methanol, acetone, acetonitrile, and hydrogen cyanide. Geophysical Research Letters, 26(8), 1161-1164. https://doi. org/10.1029/1999GL900156

Hoor, P., Fischer, H., Lange, L., Lelieveld, J., \& Brunner, D. (2002). Seasonal variations of a mixing layer in the lowermost stratosphere as identified by the $\mathrm{CO}-\mathrm{O}_{3}$ correlation from in situ measurements. Journal of Geophysical Research, 107(D5), 4044. https://doi.org/10.1029/ 2000JD000289

Hu, L., Millet, D. B., Kim, S. Y., Wells, K. C., Griffis, T. J., Fischer, E. V., et al. (2013). North American acetone sources determined from tall tower measurements and inverse modeling. Atmospheric Chemistry and Physics, 13(6), 3379-3392. https://doi.org/10.5194/acp-13-33792013

Hudson, E. D., Okuda, K., \& Ariya, P. A. (2007). Determination of acetone in seawater using derivatization solid-phase microextraction. Analytical and Bioanalytical Chemistry, 388(5-6), 1275-1282. https://doi.org/10.1007/s00216-007-1324-X

Jacob, D. J., Field, B. D., Jin, E. M., Bey, I., Li, Q., Logan, J. A., et al. (2002). Atmospheric budget of acetone. Journal of Geophysical Research, 107(D10), 4100. https://doi.org/10.1029/2001JD000694

Jaeglé, L., Jacob, D. J., Brune, W. H., \& Wennberg, P. O. (2001). Chemistry of $\mathrm{HO}_{x}$ radicals in the upper troposphere. Atmospheric Environment, 35(3), 469-489. https://doi.org/10.1016/S1352-2310(00)00376-9

Jeffery, C. D., Robinson, I. S., \& Woolf, D. K. (2010). Tuning a physically-based model of the air-sea gas transfer velocity. Ocean Modelling, 31(1-2), 28-35. https://doi.org/10.1016/j.ocemod.2009.09.001

Johnson, M. T. (2010). A numerical scheme to calculate temperature and salinity dependent air-water transfer velocities for any gas. Ocean Science, 6(4), 913-932. https://doi.org/10.5194/os-6-913-2010

Kameyama, S., Tanimoto, H., Inomata, S., Tsunogai, U., Ooki, A., Takeda, S., et al. (2010). High-resolution measurement of multiple volatile organic compounds dissolved in seawater using equilibrator inlet-proton transfer reaction-mass spectrometry (EI-PTR-MS). Marine Chemistry, 122(1-4), 59-73. https://doi.org/10.1016/j.marchem.2010.08.003

Karion, A., Sweeney, C., Wolter, S., Newberger, T., Chen, H., Andrews, A., et al. (2013). Long-term greenhouse gas measurements from aircraft. Atmospheric Measurement Techniques, 6(3), 511-526. https://doi.org/10.5194/amt-6-511-2013

Karl, T., Harley, P., Guenther, A., Rasmussen, R., Baker, B., Jardine, K., \& Nemitz, E. (2005). The bi-directional exchange of oxygenated VOCs between a loblolly pine (Pinus taeda) plantation and the atmosphere. Atmospheric Chemistry and Physics, 5(11), $3015-3031$. https://doi.org/10.5194/acp-5-3015-2005

Karl, T., Potosnak, M., Guenther, A., Clark, D., Walker, J., Herrick, J. D., \& Geron, C. (2004). Exchange processes of volatile organic compounds above a tropical rain forest: Implications for modeling tropospheric chemistry above dense vegetation. Journal of Geophysical Research, 109, D18306. https://doi.org/10.1029/2004JD004738

Kean, A. J., Grosjean, E., Grosjean, D., \& Harley, R. A. (2001). On-road measurement of carbonyls in California light-duty vehicle emissions. Environmental Science \& Technology, 35(21), 4198-4204. https://doi.org/10.1021/es010814v

Khan, M. A. H., Cooke, M. C., Utembe, S. R., Archibald, A. T., Maxwell, P., Morris, W. C., et al. (2015). A study of global atmospheric budget and distribution of acetone using global atmospheric model STOCHEM-CRI. Atmospheric Environment, 112, 269-277. https://doi.org/ 10.1016/j.atmosenv.2015.04.056

Kieber, R., Zhou, X., \& Mopper, K. (1990). Formation of carbonyl compounds from UV-induced photodegradation of humic substances in natural waters: Fate of riverine carbon in the sea. Limnology and Oceanography, 35(7), 1503-1515. https://doi.org/10.4319/ lo.1990.35.7.1503

Lamarque, J. F., Emmons, L. K., Hess, P. G., Kinnison, D. E., Tilmes, S., Vitt, F., et al. (2012). CAM-chem: Description and evaluation of interactive atmospheric chemistry in the Community Earth System Model. Geoscientific Model Development, 5(2), 369-411. https://doi. org/10.5194/gmd-5-369-2012

Lee, A., Goldstein, A. H., Keywood, M. D., Gao, S., Varutbangkul, V., Bahreini, R., et al. (2006). Gas-phase products and secondary aerosol yields from the ozonolysis of ten different terpenes. Journal of Geophysical Research, 111, D07302. https://doi.org/10.1029/2005JD006437

Liss, P. S., \& Slater, P. G. (1974). Flux of gases across the air-sea interface. Nature, 247(5438), 181-184. https://doi.org/10.1038/247181a0

Mackay, D., \& Yeun, A. T. K. (1983). Mass transfer coefficient correlations for volatilization of organic solutes from water. Environmental Science \& Technology, 17(4), 211-217. https://doi.org/10.1021/es00110a006

Marandino, C. A., Bruyn, W. J. D., Miller, S. D., Prather, M. J., \& Saltzman, E. S. (2005). Oceanic uptake and the global atmospheric acetone budget. Geophysical Research Letters, 32, L15806. https://doi.org/10.1029/2005GL023285

Marandino, C. A., Bruyn, W. J. D., Miller, S. D., \& Saltzman, E. S. (2009). Open ocean DMS air/sea fluxes over the eastern South Pacific Ocean. Atmospheric Chemistry and Physics, 9(2), 345-356. https://doi.org/10.5194/acp-9-345-2009

McManus, J. B., Nelson, D. D., Shorter, J. H., Jimenez, R., Herndon, S., Saleska, S., \& Zahniser, M. (2005). A high precision pulsed quantum cascade laser spectrometer for measurements of stable isotopes of carbon dioxide. Journal of Modern Optics, 52(16), 2309-2321. https:// doi.org/10.1080/09500340500303710

Monks, P. S. (2005). Gas-phase radical chemistry in the troposphere. Chemical Society Reviews, 34(5), 376-395. https://doi.org/10.1039/ B307982C

Müller, J.-F., \& Brasseur, G. (1999). Sources of upper tropospheric $\mathrm{HO}_{x}$ : A three-dimensional study. Journal of Geophysical Research, 104(D1), 1705-1715. https://doi.org/10.1029/1998JD100005

Navarro, M. A., Atlas, E. L., Saiz-Lopez, A., Rodriguez-Lloveras, X., Kinnison, D. E., Lamarque, J.-F., et al. (2015). Airborne measurements of organic bromine compounds in the Pacific tropical tropopause layer. Proceedings of the National Academy of Sciences, 112(45), 13,789-13,793. https://doi.org/10.1073/pnas.1511463112 
Navarro, M. A., Saiz-Lopez, A., Cuevas, C. A., Fernandez, R. P., Atlas, E., Rodriguez-Lloveras, X., et al. (2017). Modeling the inorganic bromine partitioning in the tropical tropopause layer over the eastern and western Pacific Ocean. Atmospheric Chemistry and Physics, 17(16), 9917-9930. https://doi.org/10.5194/acp-17-9917-2017

Neumaier, M., Ruhnke, R., Kirner, O., Ziereis, H., Stratmann, G., Brenninkmeijer, C. A. M., \& Zahn, A. (2014). Impact of acetone (photo) oxidation on $\mathrm{HO}_{x}$ production in the UT/LMS based on CARIBIC passenger aircraft observations and EMAC simulations. Geophysical Research Letters, 41, 3289-3297. https://doi.org/10.1002/2014GL059480

Nicely, J. M., Anderson, D. C., Canty, T. P., Salawitch, R. J., Wolfe, G. M., Apel, E. C., et al. (2016). An observationally constrained evaluation of the oxidative capacity in the tropical western Pacific troposphere. Journal of Geophysical Research: Atmospheres, 121, 7461-7488. https://doi.org/10.1002/2016JD025067

Nightingale, P. D., Malin, G., Law, C. S., Watson, A. J., Liss, P. S., Liddicoat, M. I., et al. (2000). In situ evaluation of air-sea gas exchange parameterizations using novel conservative and volatile tracers. Global Biogeochemical Cycles, 14(1), 373-387. https://doi.org/10.1029/ 1999GB900091

Pan, L. L., Bowman, K. P., Shapiro, M., Randel, W. J., Gao, R. S., Campos, T., et al. (2007). Chemical behavior of the tropopause observed during the stratosphere-troposphere analyses of regional transport experiment. Journal of Geophysical Research, 112, D18110. https:// doi.org/10.1029/2007JD008645

Pan, L. L., Randel, W. J., Gary, B. L., Mahoney, M. J., \& Hintsa, E. J. (2004). Definitions and sharpness of the extratropical tropopause: A trace gas perspective. Journal of Geophysical Research, 109, D23103. https://doi.org/10.1029/2004JD004982

Parrella, J. P., Jacob, D. J., Liang, Q., Zhang, Y., Mickley, L. J., Miller, B., et al. (2012). Tropospheric bromine chemistry: Implications for present and pre-industrial ozone and mercury. Atmospheric Chemistry and Physics, 12(15), 6723-6740. https://doi.org/10.5194/acp-126723-2012

Pedregosa, F., Varoquaux, G., Gramfort, A., Michel, V., Thirion, B., Grisel, O., et al. (2011). Scikit-learn: Machine learning in Python. Journal of Machine Learning Research, 12(Oct), 2825-2830.

Peters, D., \& Waugh, D. W. (2003). Rossby wave breaking in the Southern Hemisphere wintertime upper troposphere. Monthly Weather Review, 131(11), 2623-2634. https://doi.org/10.1175/1520-0493(2003)131\%3C2623:RWBITS\%3E2.0.CO;2

Pétron, G., Karion, A., Sweeney, C., Miller, B. R., Montzka, S. A., Frost, G. J., et al. (2014). A new look at methane and nonmethane hydrocarbon emissions from oil and natural gas operations in the Colorado Denver-Julesburg Basin. Journal of Geophysical Research: Atmospheres, 119, 6836-6852. https://doi.org/10.1002/2013JD021272

Ryerson, T., Williams, E., \& Fehsenfeld, F. (2000). An efficient photolysis system for fast-response $\mathrm{NO}_{2}$ measurements. Journal of Geophysical Research, 105(D21), 26,447-26,461. https://doi.org/10.1029/2000JD900389

Saiz-Lopez, A., \& Fernandez, R. P. (2016). On the formation of tropical rings of atomic halogens: Causes and implications. Geophysical Research Letters, 43, 2928-2935. https://doi.org/10.1002/2015GL067608

Saiz-Lopez, A., \& von Glasow, R. (2012). Reactive halogen chemistry in the troposphere. Chemical Society Reviews, 41(19), $6448-6472$. https://doi.org/10.1039/C2CS35208G

Santoni, G. W., Daube, B. C., Kort, E. A., Jiménez, R., Park, S., Pittman, J. V., et al. (2014). Evaluation of the airborne quantum cascade laser spectrometer (QCLS) measurements of the carbon and greenhouse gas suite- $\mathrm{CO}_{2}, \mathrm{CH}_{4}, \mathrm{~N}_{2} \mathrm{O}$, and $\mathrm{CO}-\mathrm{During}$ the CalNex and $\mathrm{HIPPO}$ campaigns. Atmospheric Measurement Techniques, 7(6), 1509-1526. https://doi.org/10.5194/amt-7-1509-2014

Scheeren, H. A., Fischer, H., Lelieveld, J., Hoor, P., Rudolph, J., Arnold, F., et al. (2003). Reactive organic species in the northern extratropical lowermost stratosphere: Seasonal variability and implications for OH. Journal of Geophysical Research, 108(D24), 4805. https:// doi.org/10.1029/2003JD003650

Schlundt, C., Tegtmeier, S., Lennartz, S. T., Bracher, A., Cheah, W., Krüger, K., et al. (2017). Oxygenated volatile organic carbon in the western Pacific convective center: Ocean cycling, air-sea gas exchange and atmospheric transport. Atmospheric Chemistry and Physics, 17(17), 10,837-10,854. https://doi.org/10.5194/acp-17-10837-2017

Schmidt, J. A., Jacob, D. J., Horowitz, H. M., Hu, L., Sherwen, T., Evans, M. J., et al. (2016). Modeling the observed tropospheric BrO background: Importance of multiphase chemistry and implications for ozone, OH, and mercury. Journal of Geophysical Research: Atmospheres, 121, 11,819-11,835. https://doi.org/10.1002/2015JD024229

Schwantes, R. H., Emmons, L. K., Orlando, J. J., Barth, M. C., Tyndall, G. S., Hall, S. R., et al. (2020). Comprehensive isoprene and terpene chemistry improves simulated surface ozone in the southeastern U.S. Atmospheric Chemistry and Physics, 3739-3776. https://doi.org/ 10.5194/acp-20-3739-2020

Sherwen, T., Schmidt, J. A., Evans, M. J., Carpenter, L. J., Großmann, K., Eastham, S. D., et al. (2016). Global impacts of tropospheric halogens $(\mathrm{Cl}, \mathrm{Br}, \mathrm{I})$ on oxidants and composition in GEOS-Chem. Atmospheric Chemistry and Physics, 16(18), 12,239-12,271. https://doi org/10.5194/acp-16-12239-2016

Shetter, R. E., \& Müller, M. (1999). Photolysis frequency measurements using actinic flux spectroradiometry during the PEM-Tropics mission: Instrumentation description and some results. Journal of Geophysical Research, 104(D5), 5647-5661. https://doi.org/10.1029/ 98JD01381

Singh, H., Chen, Y., Tabazadeh, A., Fukui, Y., Bey, I., Yantosca, R., et al. (2000). Distribution and fate of selected oxygenated organic species in the troposphere and lower stratosphere over the Atlantic. Journal of Geophysical Research, 105(D3), 3795-3805. https://doi.org/ 10.1029/1999JD900779

Singh, H. B. (2004). Analysis of the atmospheric distribution, sources, and sinks of oxygenated volatile organic chemicals based on measurements over the Pacific during TRACE-P. Journal of Geophysical Research, 109, D15S07. https://doi.org/10.1029/2003JD003883

Singh, H. B., Kanakidou, M., Crutzen, P. J., \& Jacob, D. J. (1995). High concentrations and photochemical fate of oxygenated hydrocarbons in the global troposphere. Nature, 378(6552), 50-54. https://doi.org/10.1038/378050a0

Singh, H. B., O'Hara, D., Herlth, D., Sachse, W., Blake, D. R., Bradshaw, J. D., et al. (1994). Acetone in the atmosphere: Distribution, sources, and sinks. Journal of Geophysical Research, 99(D1), 1805-1819. https://doi.org/10.1029/93JD00764

Taddei, S., Toscano, P., Gioli, B., Matese, A., Miglietta, F., Vaccari, F. P., et al. (2009). Carbon dioxide and acetone air-sea fluxes over the southern Atlantic. Environmental Science \& Technology, 43(14), 5218-5222. https://doi.org/10.1021/es8032617

Tanimoto, H., Kameyama, S., Iwata, T., Inomata, S., \& Omori, Y. (2014). Measurement of air-sea exchange of dimethyl sulfide and acetone by PTR-MS coupled with gradient flux technique. Environmental Science \& Technology, 48(1), 526-533. https://doi.org/10.1021/ es4032562

Tilmes, S., Lamarque, J.-F., Emmons, L. K., Kinnison, D. E., Ma, P.-L., Liu, X., et al. (2015). Description and evaluation of tropospheric chemistry and aerosols in the Community Earth System Model (CESM1.2). Geoscientific Model Development, 8(5), 1395-1426. https:// doi.org/10.5194/gmd-8-1395-2015 
van der Werf, G. R., Randerson, J. T., Giglio, L., van Leeuwen, T. T., Chen, Y., Rogers, B. M., et al. (2017). Global fire emissions estimates during 1997-2016. Earth System Science Data, 9(2), 697-720. https://doi.org/10.5194/essd-9-697-2017

Wang, S., Emmons, L. K., Marandino, C. A., Bruyn, W. J. D., Saltzman, E. S., Tanimoto, H., et al. (2020). Surface seawater concentration of acetone: Monthly climatology. https://doi.org/10.5065/cg38-b505

Wang, S., Hornbrook, R. S., Hills, A., Emmons, L. K., Tilmes, S., Lamarque, J.-F., et al. (2019). Atmospheric acetaldehyde: Importance of air-sea exchange and a missing source in the remote troposphere. Geophysical Research Letters, 46, 5601-5613. https://doi.org/10.1029/ 2019GL082034

Wang, S., Kinnison, D., Montzka, S. A., Apel, E. C., Hornbrook, R. S., Hills, A. J., et al. (2019). Ocean biogeochemistry control on the marine emissions of brominated very short-lived ozone-depleting substances: A machine-learning approach. Journal of Geophysical Research: Atmosphere, 124, 12,319-12,339. https://doi.org/10.1029/2019JD031288

Wang, X., Jacob, D. J., Eastham, S. D., Sulprizio, M. P., Zhu, L., Chen, Q., et al. (2019). The role of chlorine in global tropospheric chemistry Atmospheric Chemistry and Physics, 19(6), 3981-4003. https://doi.org/10.5194/acp-19-3981-2019

Wennberg, P. O., Hanisco, T. F., Jaegle, L., Jacob, D. J., Hintsa, E. J., Lanzendorf, E. J., et al. (1998). Hydrogen radicals, nitrogen radicals, and the production of $\mathrm{O}_{3}$ in the upper troposphere. Science, 279(5347), 49-53.

Wiedinmyer, C., Akagi, S. K., Yokelson, R. J., Emmons, L. K., Al-Saadi, J. A., Orlando, J. J., \& Soja, A. J. (2011). The Fire INventory from NCAR (FINN): A high resolution global model to estimate the emissions from open burning. Geoscientific Model Development, 4(3), 625-641. https://doi.org/10.5194/gmd-4-625-2011

Wofsy, S. C., Afshar, S., Allen, H.M., Apel, E., Asher, E.C., Barletta, B., et al. (2018). ATom: Merged atmospheric chemistry, trace gases, and aerosols. ORNL DAAC. https://doi.org/10.3334/ORNLDAAC/1581

Yang, M., Beale, R., Liss, P., Johnson, M., Blomquist, B., \& Nightingale, P. (2014). Air-sea fluxes of oxygenated volatile organic compounds across the Atlantic Ocean. Atmospheric Chemistry and Physics, 14(14), 7499-7517. https://doi.org/10.5194/acp-14-7499-2014

Yang, M., Blomquist, B. W., \& Nightingale, P. D. (2014). Air-sea exchange of methanol and acetone during HiWinGS: Estimation of air phase, water phase gas transfer velocities. Journal of Geophysical Research: Oceans, 119, 7308-7323. https://doi.org/10.1002/ 2014JC010227

Yuan, B., Shao, M., Lu, S. H., \& Wang, B. (2010). Source profiles of volatile organic compounds associated with solvent use in Beijing, China. Atmospheric Environment, 44(15), 1919-1926. https://doi.org/10.1016/j.atmosenv.2010.02.014

Zhou, X., \& Mopper, K. (1997). Photochemical production of low-molecular-weight carbonyl compounds in seawater and surface microlayer and their air-sea exchange. Marine Chemistry, 56(3-4), 201-213. https://doi.org/10.1016/S0304-4203(96)00076-X 